\title{
LAS TÚNICAS RUPESTRES PINTADAS DE LA CUENCA MEDIA Y ALTA DEL LOA VISTAS DESDE QUILLAGUA (NORTE DE CHILE)
}

\author{
THE PAINTED TUNICS OF THE MIDDLE AND UPPER LOA BASIN VIEWED \\ FROM QUILLAGUA (NORTHERN CHILE)
}

\author{
${\text { Bárbara } \text { Cases }^{1} \text { e Indira Montt }}^{2}$
}

\begin{abstract}
Desde el período Formativo (700 a.C-700 d.C.) Quillagua (Loa Inferior) acusa la interacción entre poblaciones de las regiones de Tarapacá y de Atacama, siendo particularmente notable en el período Intermedio Tardío (900-1400 d.C.). Uno de los indicadores clave de esta interacción fueron los textiles depositados en sus contextos funerarios, dentro de los cuales las túnicas ofrecen diferencias formales entre una y otra región. Sobre esta base, se revisa y discute un conjunto de pinturas rupestres antropomorfas representadas con túnicas, pertenecientes a los cursos medio y alto del Loa. Con estos datos, se ensaya una interpretación de las figuras parietales, ampliando el modelo de zona cotradicional o de frontera blanda planteada previamente para la localidad de Quillagua, a la cuenca media y alta del río Loa.
\end{abstract}

Palabras claves: textiles, túnicas, pinturas rupestres, río Loa, Tarapacá, Atacama.

Since the Formative Period (700 B.C. - A.D. 700), Quillagua (Lower Loa river basin) has demonstrated social interaction with populations from the adjacent Tarapacá and Atacama regions, an interaction that is particularly conspicuous during the Late Intermediate Period (A.D. 900 - 1400). The primary indicators of this interaction are textiles from funerary contexts, particularly tunics that show differences in shape and are associated with different regions. In this context, we present an analysis of a group of anthropomorphic paintings from the Middle and Upper Loa River region that depict individuals in tunics. Our analyses of rock art figures allow us to suggest that the co-traditional or "soft-border" zone models presented for Quillagua can be extended to the rest of the Loa river basin.

Key words: Textiles, tunics, rock art, Loa River, Tarapacá, Atacama.

El criador formó de barro (...) las naciones todas que hay en la tierra, pintando a cada una el traje y vestido que habían de tener (Cobo 1956 [1653]) [énfasis nuestro].

La formulación de secuencias históricoculturales locales en el río Loa ha considerado al registro cerámico de San Pedro de Atacama y las vinculaciones con éste como principal indicador cronológico y cultural (Agüero et al. 1999; Aldunate y Castro 1981; Ayala 2000; Cáceres y Berenguer 1996; Cervellino y Téllez 1980; Gallardo et al. 1993; López 1979; Sinclaire 2004; Uribe 2002, Uribe et al. 2002). Esto ha redundado en el reconocimiento de un territorio coherente con una unidad cultural, la Atacameña. En consecuencia, en el Loa ha sido esporádica la apertura a percibir este espacio como compartido o culturalmente permeable, ya que, con raras excepciones, a este vínculo se le atribuye un carácter meramente anecdótico (Cáceres y Berenguer 1996; Berenguer 2004a; Pimentel y Montt 2008).
Solamente la localidad de Quillagua (Figura 1) ha sido investigada como un escenario de interacción, donde atacameños y tarapaqueños produjeron una territorialidad basada en la negociación, evidente en la cultura material, a lo que nos referimos en el siguiente acápite (Agüero et al. 1999, 2006).

Aunque en el arte rupestre este vínculo ya había sido propuesto (Berenguer 1999, 2004a; Montt 2005), nos sorprendió que un conjunto de pinturas del sector Alto y Medio del río Loa mostrara elementos y rasgos que aludían consistentemente a Tarapacá. Se trata de una muestra de figuras humanas pintadas y ataviadas con túnicas. Las prendas parietales muestran correlación con sus símiles textiles, cuyas formas han sido hasta ahora indicadores de identidad, a nivel de vestuario, entre atacameños y tarapaqueños durante el Período Intermedio Tardío (900-1400 d.C.) (Agüero et al. 1999; Agüero 2007). La vestimenta sirvió como un recurso de distinción social, algo que en la localidad de Quillagua tuvo particulares expresiones desde el Formativo en

\footnotetext{
Programa de Postgrado en Antropología,Universidad de Tarapacá, barbara_cases@yahoo.es

2 Programa de Doctorado en Antropología, Universidad Católica del Norte y Universidad de Tarapacá, Instituto de Investigaciones Arqueológicas y Museo, Chile. indiramontt@gmail.com
} 


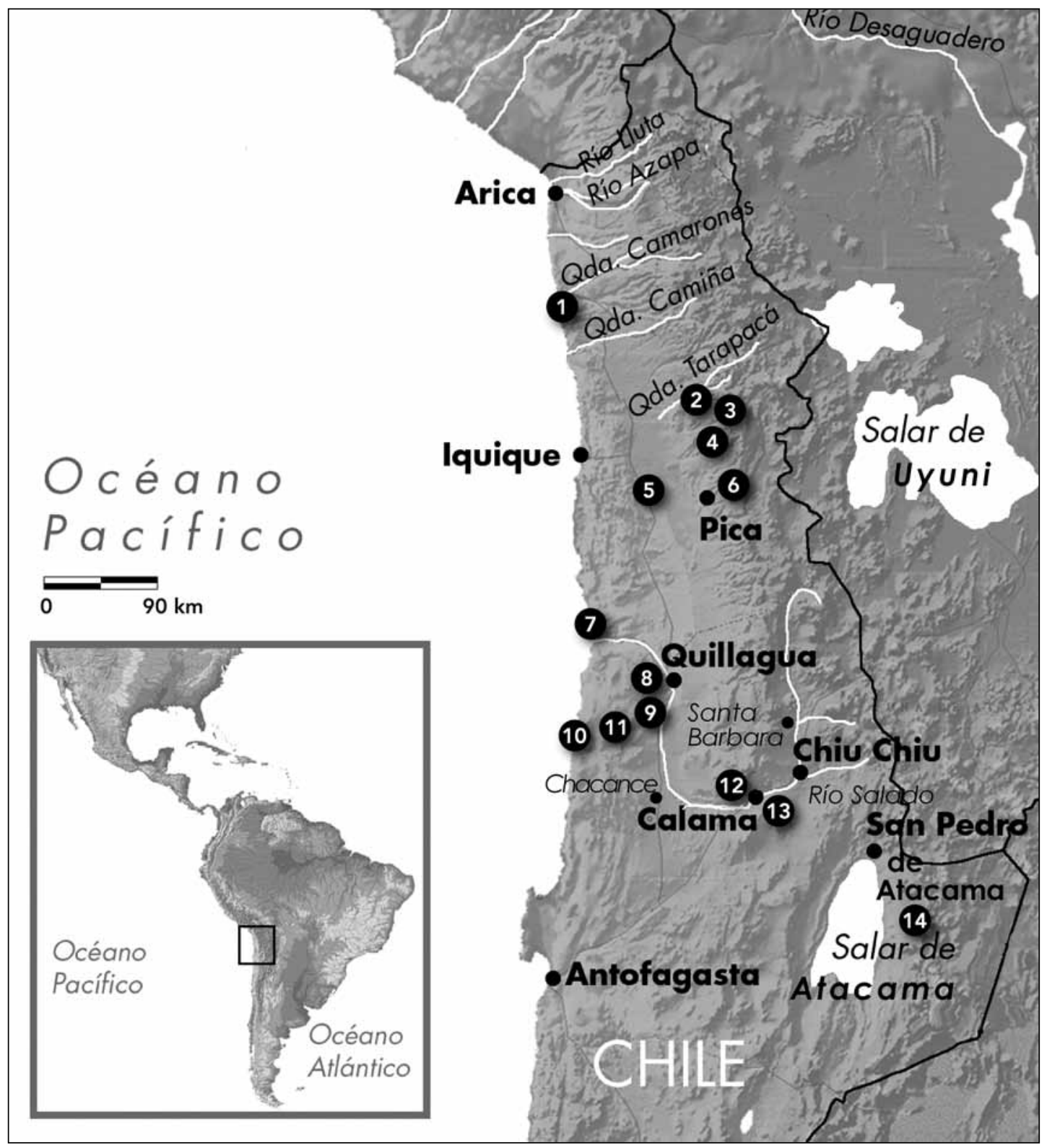

Figura 1. Mapa con localidades y sitios mencionados en el texto. 1. Camarones-15; 2. Tarapacá-40; 3. Jamajuga; 4. Ariquilda-1; 5. Pintados; 6. Pica-8; 7. Desembocadura del río Loa; 8. Cementerios Oriente y Poniente, Aldea La Capilla; 9. La Encañada; 10. Tocopilla; 11. María Elena; 12. San Salvador, Ojos de Opache; 13. Topater, Chorrillos, Yalquincha; 14. Cueva San Lorenzo. Map of the localities and sites mentioned in the text. 1. Camarones-15; 2. Tarapacá-40; 3. Jamajuga; 4. Ariquilda-1; 5. Pintados; 6. Pica-8; 7. Mouth of the Loa River; 8. Cementerios Oriente y Poniente, Aldea La Capilla; 9. La Encañada; 10. Tocopilla; 11. María Elena; 12. San Salvador, Ojos de Opache; 13. Topater, Chorrillos, Yalquincha; 14. Cueva San Lorenzo.

adelante. Es por esta razón que para abordar este grupo iconográfico rupestre del Loa Medio y Alto hemos tomado el modelo de interacción conocido para el Loa Inferior, específicamente en la localidad de Quillagua, como un medio para discutir, ensayar y comprender las relaciones entre estos grupos en el curso superior del Loa. Mediante este ejercicio se amplían las posibilidades de este modelo a un territorio que, desde la arqueología, se ha concebido fundamentalmente como atacameño. 


\section{Quillagua y la Interacción entre Atacama y Tarapacá}

...en las tierras que pertenecen a esta jurisdicción [de Tarapacá], que son las de abajo porque las de arriba son pertenecientes á Atacama y las divide una lomada que hace, en la cual hay un palo muy grueso bien acepillado formado de la gentilidad en donde está una pintura, arriba de él, que en una y otra parte hay algarrobos, los de abajo desde dicho lindero pertenecen á esta jurisdicción hasta el mar y los de arriba á la de Atacama... (Paz Soldán 1878: 56, en Martínez 1998: 125) [énfasis nuestro].

En la historia de la investigación las cuencas del río Loa y del Salar de Atacama fueron consideradas por los pioneros de la arqueología como una unidad territorial y cultural (Boman 1908; Latcham 1938; Oyarzún 1931; Uhle 1913). Tras varias décadas de investigaciones locales en la cuenca del Loa, se ha reconsiderado esta noción de unidad cultural y territorial reconociendo que distintos sectores de este río, además de relacionarse entre sí y con los oasis de San Pedro de Atacama, muestran vinculaciones diferenciales con territorios aledaños -región de Tarapacá, Valles Occidentales, Altiplano Meridional y Noroeste Argentino- cuya importancia cambia a través del tiempo (Adán 1996; Adán y Uribe 1995; Agüero et al. 1999; Agüero et al. 2006; Ayala 2000; Ayala et al. 1999; Castro et al. 1994; Sinclaire 2004; Uribe 1996, 2002).

Desde la arqueología, dicha unidad se sustentaría materialmente en ciertos rasgos compartidos en ambas cuencas, a nivel de arquitectura, cerámica, funebria y textiles como en datos etnohistóricos (Adán y Uribe 1995, 1999; Agüero 2007; Agüero et al. 1999; Ayala et al. 1999; Cases 2007; Manríquez 2002; Martínez 1998; Montt 2002a; Uribe 2002; Varela et al. 1993). En términos espaciales, la región atacameña comprende el territorio ocupado por las poblaciones que etnohistóricamente se denominaron "atacamas", es decir, los grupos que en el siglo XVI se concentraban en la cuenca del Loa, los oasis del Salar de Atacama y la puna aledaña, ocupando lo que hoy se conoce como la subárea Circumpuneña (Sanhueza 1992) (Figura 2). ${ }^{1}$

Por su parte, la región de Tarapacá comprende el extremo sur de la subárea de Valles Occidentales, entre los ríos Camarones y Loa, por el norte y el sur, respectivamente, colindando por el este con la subárea Altiplano Meridional (Agüero 2007: 10) (Figs. 1 y 2). ${ }^{2}$ Los antecedentes arqueológicos sugieren una continuidad cultural de los habitantes de esta región entre los períodos Formativo e Intermedio Tardío, de acuerdo con indicadores materiales de carácter local, en particular textiles y cerámicos (Agüero 2007; Uribe 2006; Uribe 2009; Uribe et al. 2007).

En este contexto, Quillagua, en el Loa Inferior, evidenció cultura material que daba cuenta de una historia social permeada por relaciones entre poblaciones de Tarapacá y Atacama, siendo los textiles, y específicamente las túnicas, uno de los indicadores más elocuentes en este sentido, como veremos en detalle más adelante (Agüero et al. 1999, 2006; Agüero 2007).

En efecto, el Formativo Temprano (700-135 a.C.) abre esta historia con la construcción de túmulos ceremoniales y el uso inicial de cementerios, ambos en las terrazas altas cercanas a la pampa. En los cementerios se depositó a los muertos en fosas, envueltos sólo en una manta, sin más ofrenda que algunos restos vegetales, cestos, cerámica del Loa y ocasionalmente una bolsa de fibra vegetal. Los materiales recuperados en estos sitios funerarios muestran que Quillagua estableció vínculos con el resto de la cuenca del Loa, incluyendo a la costa y, en menor medida, con sitios de la región de Tarapacá, existiendo igualmente aportes locales como la industria de perforadores y microperforadores de calcedonia (Agüero et al. 2006).

Por su parte, durante el Formativo Tardío (500-700 d.C.), en los mismos sitios se constata la práctica local de ofrendar placas de cal, junto a alfarería tarapaqueña y a una variación local de ésta, además de pendientes de turquesa de funcionalidad desconocida, recuperándose en los túmulos, placas de metal, cuentas, agujas y textiles miniatura tarapaqueños (Agüero et al. 2006). Los materiales sugieren las mismas vinculaciones que en épocas más tempranas, aunque con una mayor impronta de la región de Tarapacá, agregándose túnicas y gorros registrados también en sitios del Formativo Tardío del valle de Azapa, siendo menos evidentes las relaciones con los oasis de San Pedro de Atacama (Agüero y Cases 2004).

Siguiendo con la secuencia de interacción que observamos en Quillagua, entre 700-800 d.C. se habría iniciado la construcción de la aldea La Capilla (Cervellino y Téllez 1980; López 1979). El 


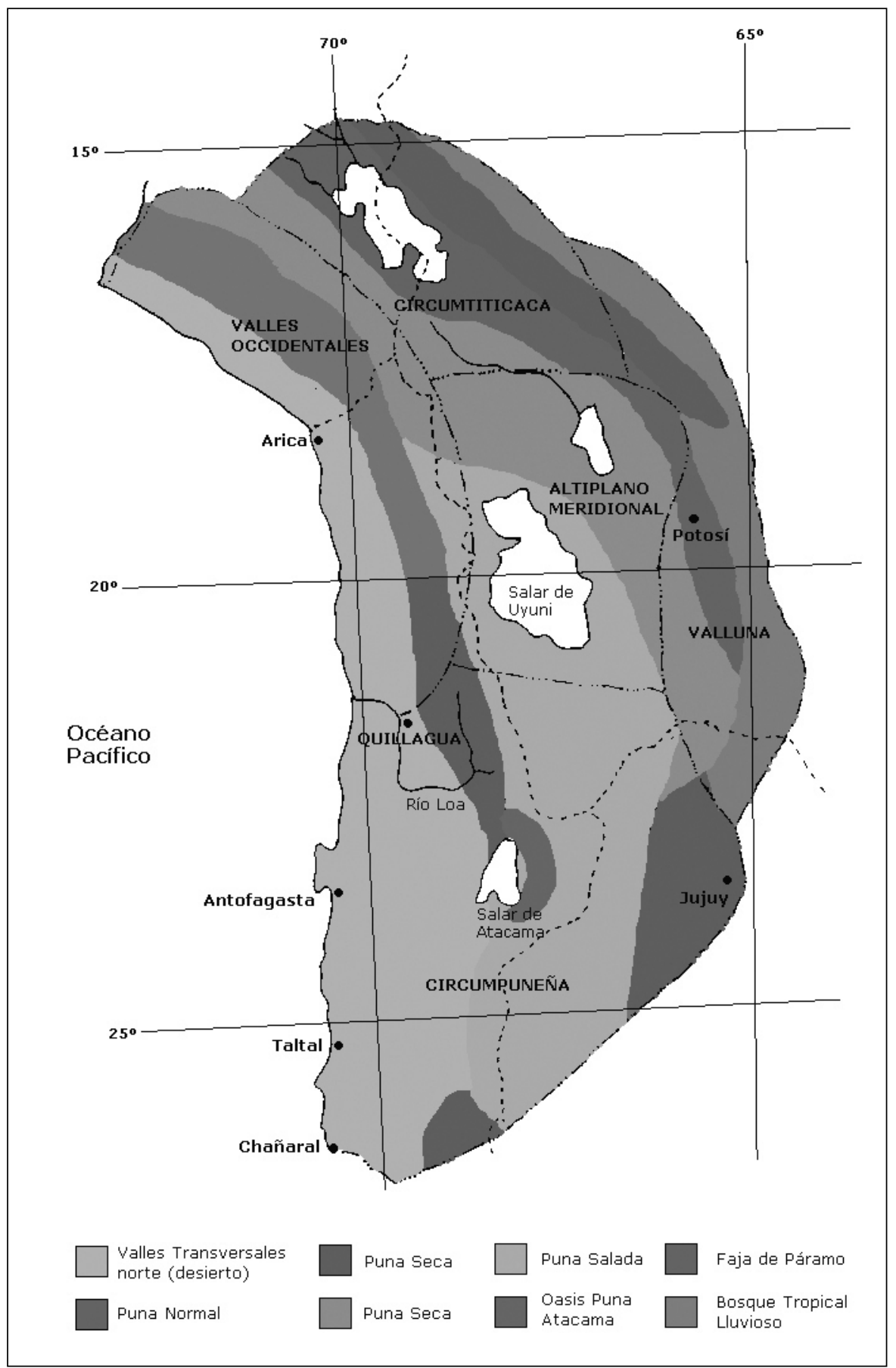

Figura 2. Ubicación de las subáreas Valles Occidentales y Circumpuneña en los Andes Centro-Sur y sus franjas ambientales. (Adaptado de Aldunate y Castro 1981 y Núñez 1984).

Location of the Occidental Valleys and Circumpuneña subareas in the South Central Andes and their environmental zones (Adapted from Aldunate and Castro 1981 and Núñez 1984). 
temprano Intermedio Tardío (900-1.300 d.C.) inaugura una convivencia más estrecha entre poblaciones de Tarapacá y Atacama, como veremos más adelante, a partir de la información textil (Agüero et al. 1999). Durante estos momentos, la presencia tarapaqueña se materializa en objetos cerámicos y textiles dentro de los contextos funerarios de los cementerios Oriente y Oriente Alto; en tanto, en la aldea La Capilla hay material cerámico que evidencia una ocupación inicial con predominio del componente cerámico Loa-San Pedro y una mínima participación de materiales del extremo norte de Chile y de Tarapacá (Gallardo et al. 1993; Uribe 1996; Agüero et al. 1999). En el tardío Intermedio Tardío (1.300-1.450 d.C.), la ocupación humana se concentra en la banda poniente del Loa y perdura hasta al menos la llegada de influencias incaicas a la zona. En estos momentos se observa la ausencia de cerámica de Tarapacá, tanto en la aldea como en el Cementerio Poniente, donde se detectan principalmente tejidos atacameños (Agüero et al. 1999). De acuerdo a los autores, lo anterior indicaría que a diferencia de momentos previos, la otrora frontera septentrional "blanda" de Atacama, establecida en este segmento del río Loa, se vuelve "dura" frente a las influencias posibles de ser establecidas con Tarapacá (Agüero et al. 1999). Esto coincidiría con el fortalecimiento de la identidad atacameña en las cuencas del Loa y de Atacama, la que se vio acompañada de una mayor apropiación de elementos de raigambre altiplánica, junto con el auge de tecnologías agrohidráulicas en la subárea circumpuneña (Uribe et al. 2002).

La presencia de rutas, estructuras aisladas y arte rupestre emplazados en la periferia respecto al núcleo ocupacional (Gallardo et al. 1993), junto al hallazgo de cuerdas, cencerros, ganchos de atalaje, costales y restos de camélidos en los contextos funerarios dan cuenta de viajes de caravanas, entre Quillagua, la costa y otros ámbitos del Loa y Tarapacá. En los geoglifos de La Encañada se han identificado motivos antropomorfos con túnicas trapezoidales tarapaqueñas de orilla recta y de orilla curva (Pimentel y Montt 2008:40-42, Figs. 3, 4 y 5; Figura 3).

En síntesis, la continuidad detectada entre las ocupaciones del Formativo con aquellas de los inicios del Intermedio Tardío indicaría que hacia el final del primer milenio de nuestra era Atacama y Tarapacá contaban con una extensa historia de interacción en Quillagua, siendo evidente el paso entre un momento inicial del período Intermedio
Tardío vinculado a Tarapacá hacia uno más tardío y cercano con Atacama.

\section{Referentes para las Pinturas Rupestres: Túnicas y Taparrabos de Tarapacá y Atacama}

Las túnicas halladas en los cementerios del curso medio e inferior del río Loa constituyen los referentes más plausibles para tratar las pinturas rupestres objeto de este artículo, las que se ubican en los cursos medio y alto de este río. Esto, debido a que en el sector alto no existen cementerios ni se conservan textiles. En la desembocadura de este río sólo se han registrado algunos fragmentos textiles del período Formativo y del final del Intermedio Tardío (Agüero et al. 1999; Agüero y Cases 2004).

Estamos conscientes de que los alcances de un análisis rupestre frente a su contraparte textil se ven limitados por la dificultad de reconocer en las pinturas que analizamos rasgos propios de los tejidos, como técnicas de manufactura, decoración y colores. Por esta razón, en este ensayo abordamos la morfología de las túnicas como el rasgo más evidente con fines comparativos, a fin de poder ampliar el potencial interpretativo del arte rupestre. Destacamos nuevamente que nuestro registro parietal se emplaza en un territorio en que el dato textil es prácticamente inexistente; por tanto, nuestra aproximación permite extender planteamientos derivados de la investigación de los tejidos a un área en que el repertorio iconográfico sustituye al dato textil.

Entrando en materia, durante el Formativo la túnica es una prenda que sólo se deposita ocasionalmente como parte del ajuar funerario, haciéndose más populares hacia el final del período. Son de forma cuadrada o rectangular, de alto inferior al ancho o al revés (Figura 4 y Tabla 1) y se distribuyen indistintamente en los valles de Azapa y Camarones, en la región de Tarapacá y el cementerio de Topater en el Loa Medio (Agüero y Cases 2004). Si consideramos que los tejidos miniatura han sido considerados parte de la textilería característica de Tarapacá, dentro de las que se incluyen aquellas encontradas en el Valle de Azapa y en Quillagua, contaríamos con un referente para las túnicas tarapaqueñas que indican formas cuadradas o de ancho mayor al alto. San Pedro de Atacama, por su parte, con túnicas cuya asignación al Formativo es objeto de debate, muestra formas rectangulares de alto superior al ancho y, en menor medida, de largo mayor al ancho (Agüero y Cases 2004). 
(a)

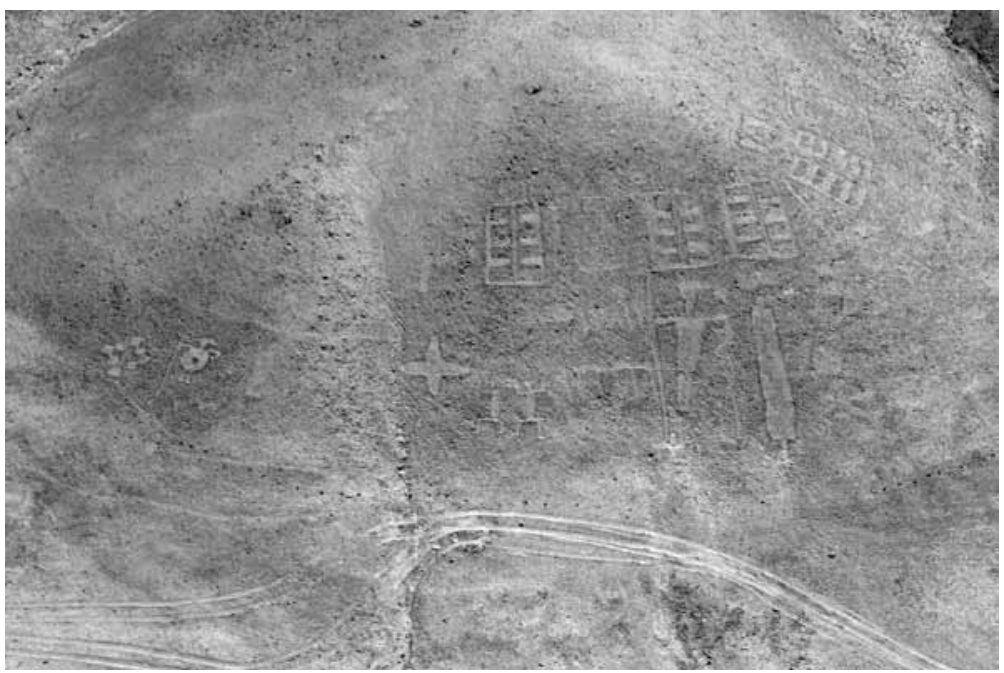

(b)

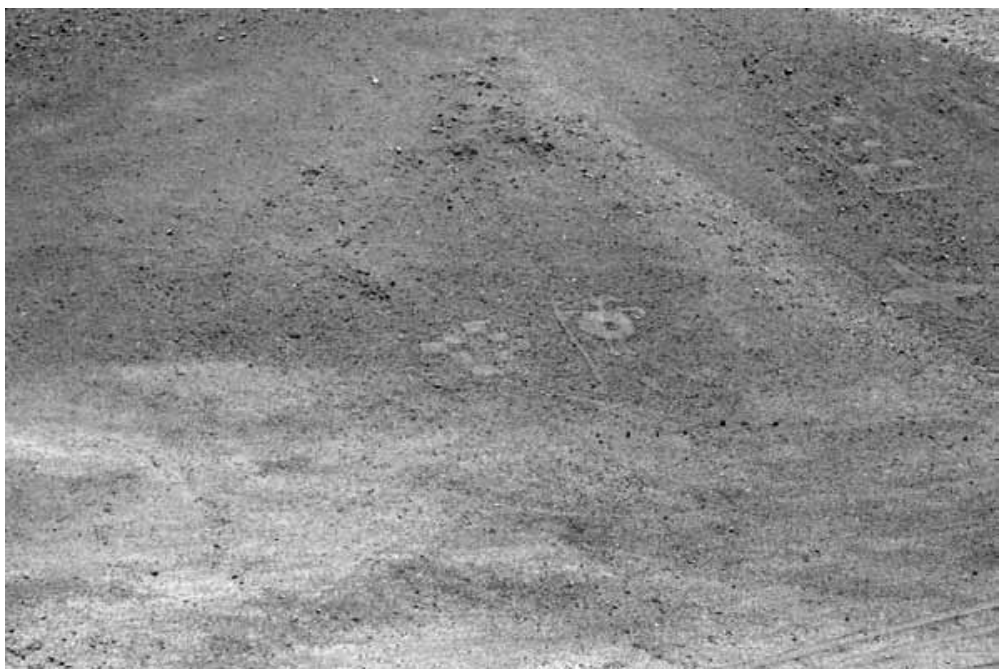

(c)

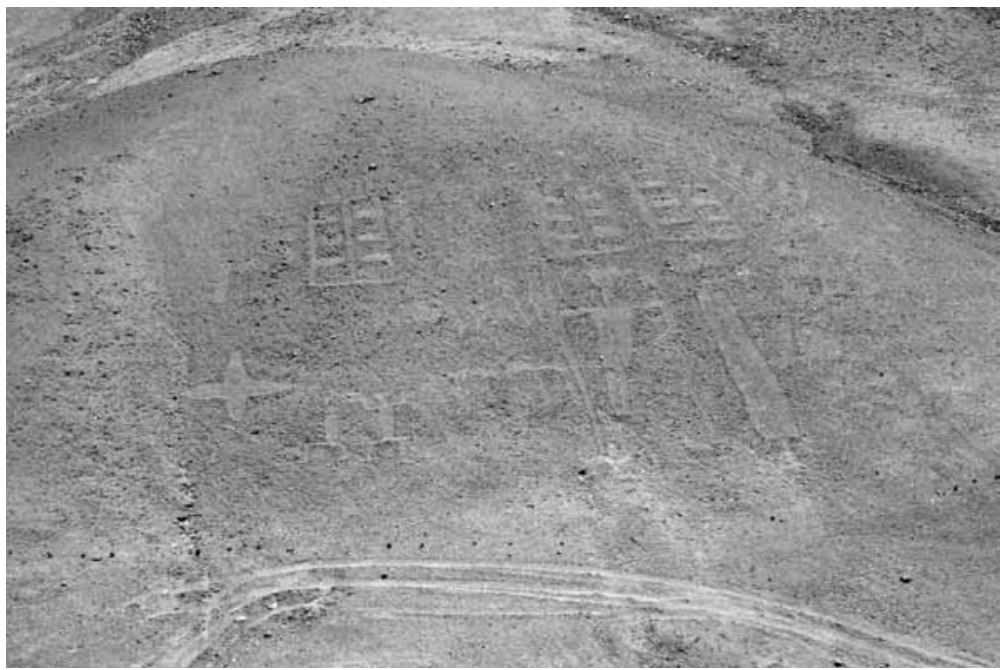

Figura 3. (a) Geoglifos de La Encañada; detalles de (b) túnica trapezoidal de orilla curva y (c) túnica de orilla recta.

(a) Geoglyphs from La Encañada; details of (b) trapezoidal tunic with curved lower border and (c) tunic with straight lower border. 


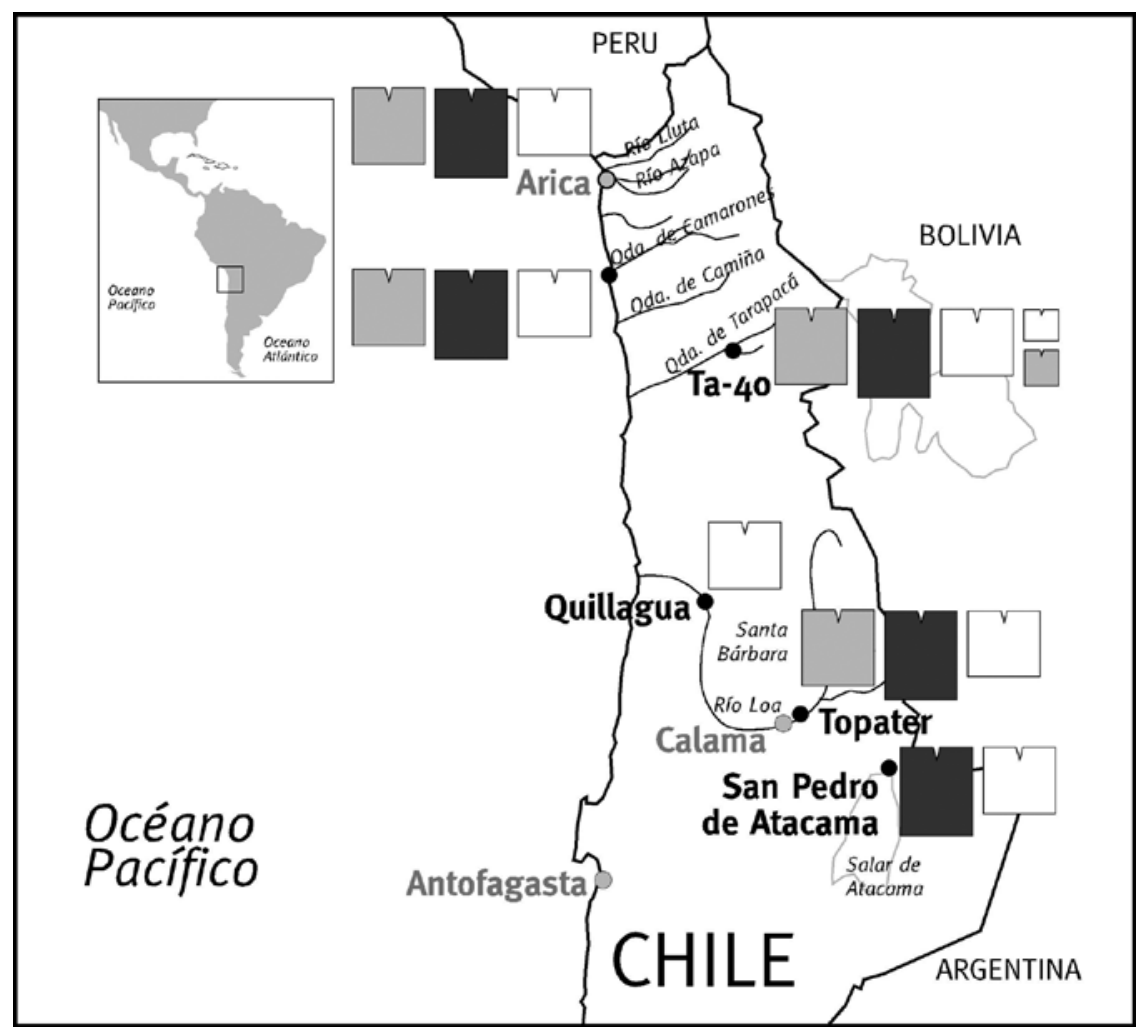

Figura 4. Mapa de distribución de formas de túnicas en el Período Formativo, ordenadas de izquierda a derecha, de mayor a menor frecuencia, basados en el registro textil (Agüero y Cases 2000).

Map of the distribution of Formative Period tunic formats, ordered according to decreasing frequency ( $L$ to $R)$ based on the textile record (Agüero and Cases 2000).

Tabla 1. Distribución de formas de túnicas textiles durante el período Formativo (círculos en negro muestran predominio absoluto).

Forms of textile tunics during the Formative Period (circles in black show absolute predominance).

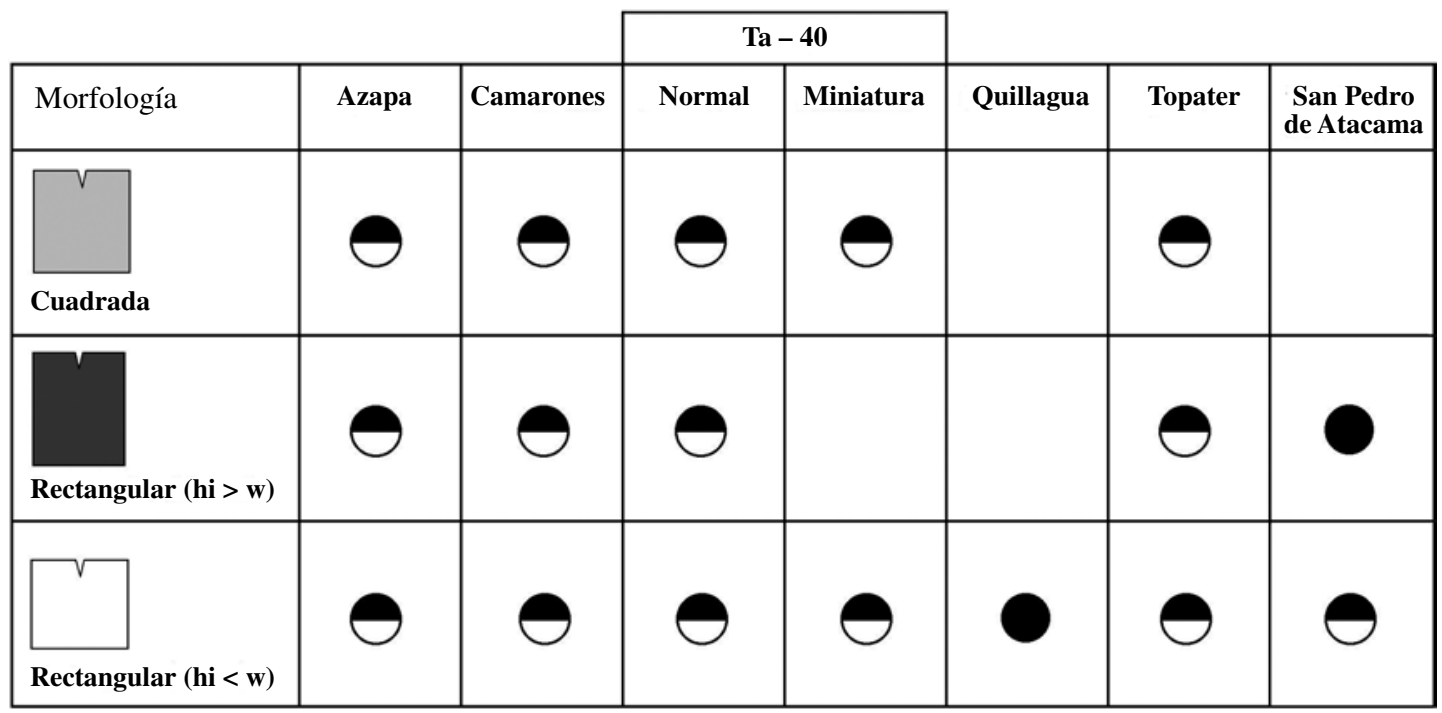


Dentro de las túnicas del período Formativo, destacamos un grupo que se caracteriza por combinar el tejido en faz de urdimbre en el cuerpo y un borde inferior en faz de trama (Agüero y Cases 2004). Éstas son de forma cuadrada o rectangular alta, presentando diversas variantes según la disposición de colores y técnicas de tejido más específicas; cuentan con una distribución espacial que abarca desde el extremo norte de nuestro país hasta el curso medio del río Loa (Agüero y Cases 2004; Cases et al. 2008). De este grupo, la variante mejor conocida en la literatura especializada es un conjunto de tres túnicas, provenientes de los valles de Azapa y Camarones, cuyo borde inferior presenta rostros radiados logrados por técnica de tapicería (Agüero y Cases 2004; Horta 2004). Volveremos sobre este grupo al tratar una pintura del Alto Loa.

En suma, puede observarse que, salvo por las miniaturas, la distribución de formas no ofrece claves morfológicas significativas para identificar posibles distinciones de procedencia en este período (Figura 3 y Tabla 1).

Otra prenda textil que, como veremos más adelante, se puede identificar en las pinturas rupestres son los taparrabos. Esta es una prenda textil que se ha registrado sólo en algunos cementerios, y aquellos que podrían estar representados en las pinturas antropomorfas de las que trata este artículo corresponderían a piezas que ya fueron vinculadas al arte rupestre por Sinclaire (1997). Al igual que las túnicas contemporáneas señaladas más arriba, estos taparrabos del Formativo Tardío combinan el tejido en faz de urdimbre con técnica de tapicería, cuya iconografía se vincula con el estilo de arte rupestre Cueva Blanca del Formativo Tardío (Gallardo et al. 1999; vide infra). De acuerdo a Sinclaire (1997), el sector en faz de urdimbre se dispone entre las piernas mientras los módulos con decoración en tapicería penden por delante y por detrás del cuerpo. Este consistente grupo de taparrabos se ha registrado en el cementerio de Topater, en Chorrillos y San Salvador en el Loa Medio (Sinclaire 1997); igualmente, tenemos noticia de su hallazgo en una tumba aislada entre María Elena y Tocopilla como en Caleta Lautaro, cerca de la desembocadura del río Loa (ambas comunicaciones personales de Claudio Castellón a B. Cases, 1997). Nos parece importante destacar que en cementerios formativos de la costa e interior de la región de Tarapacá se han registrado taparrabos con una combinación de técnicas similar -faz de urdimbre y ligamento tela en el cuerpo y faz de trama en paneles frontal y posterior-, pero tienen forma de clepsidra y listas horizontales en faz de trama (Agüero y Cases 2004).

A diferencia de las túnicas del Formativo, las del Intermedio Tardío son más sugerentes en términos de establecer asignaciones regionales (Figura $5 \mathrm{y}$ Tabla 2). Aunque las túnicas rectangulares y cuadradas son frecuentes en el registro textil de este período, la tradición textil de Valles Occidentales en la cual se insertan los tejidos tarapaqueños ha sido caracterizada en publicaciones especializadas por una tendencia a presentar túnicas trapezoidales o semitrapezoidales (Agüero 2000a, 2007). Estas morfologías de túnicas marcan una diferencia con aquellas de la tradición textil atacameña, que se caracterizan por formas predominantemente cuadradas a rectangulares (Agüero 2000b). Aunque los rasgos técnicos textiles específicos no constituyen un elemento visible ni contrastable en el arte rupestre, existen diferencias que desde el Intermedio Tardío permiten establecer variaciones entre los tejidos de las tradiciones textiles de Valles Occidentales y de Atacama (Agüero et al. 1999). Nos referimos en específico al número de tramas con que se tejieron: una sola trama o tramas múltiples, respectivamente, que implican soluciones y acciones técnicas diferentes que se realizan en los bordes laterales del textil, con la función de delimitar o cerrar el espacio tejido. Este aspecto es fundamental en la obtención de un tejido de buena calidad (Arnold 2000; Arnold y Espejo 2005). Nos parece que podría existir una relación entre la manera de cerrar el espacio textil y la forma en que el arte rupestre cierra o delimita un territorio, aspecto sobre el cual volveremos al final del artículo.

De este modo, las túnicas del complejo PicaTarapacá son semitrapezoidales, tejidas con una sola trama, pudiendo tener la orilla de urdimbre recta o curva; esta última forma constituye un atributo inequívocamente tarapaqueño y en ellas es mayor el ancho, a diferencia de las de orilla de urdimbre recta, en las que prevalece el alto (Agüero 2007; Agüero et al. 1999:186, Fig. 13). De acuerdo a los datos de Agüero (2007: 49-55), este conjunto representa cerca del $85 \%$ de las túnicas que registra en Pica 8, dentro de las cuales predomina ligeramente la orilla curva por sobre la recta.

Durante este período la cuenca del Loa muestra situaciones diferenciales entre su curso inferior y medio. En todos los cementerios de Quillagua es numéricamente mayor la forma cuadrada, que supera 


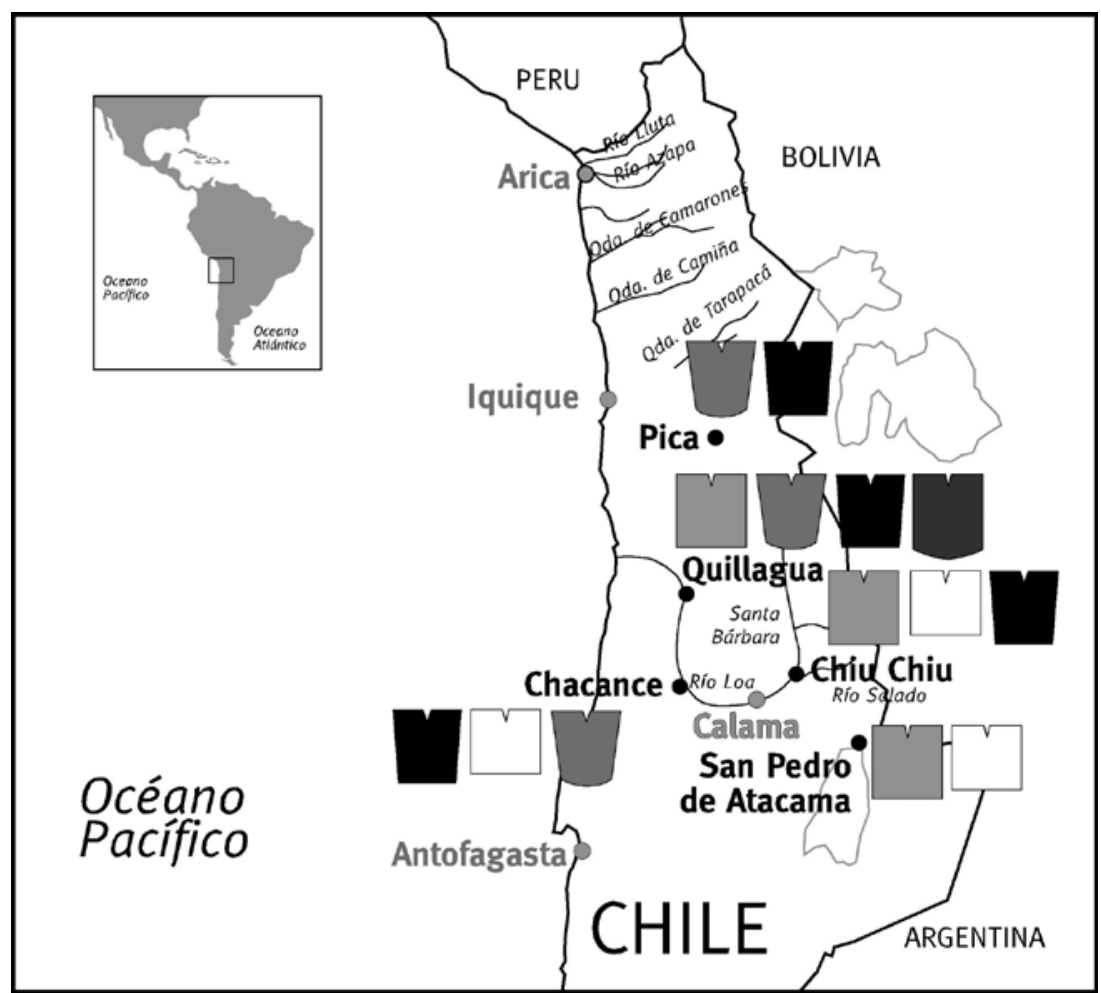

Figura 5. Distribución de formas de túnicas textiles en el Período Intermedio Tardío, ordenadas de izquierda a derecha, de mayor a menor frecuencia basado en los datos de Agüero (2007).

Distribution of tunic formats during the Late Intermediate Period, ordered according to decreasing frequency $(L$ to $R)$, based on data published by Agüero (2007).

Tabla 2. Distribución de formas de túnicas textiles durante el Período Intermedio Tardío (círculos en negro muestran predominio absoluto, círculos en blanco muestran las menores frecuencias). Forms of textile tunics during the Late Intermediate Period (circles in black show absolute predominance, circles in white show the lowest frequencies).

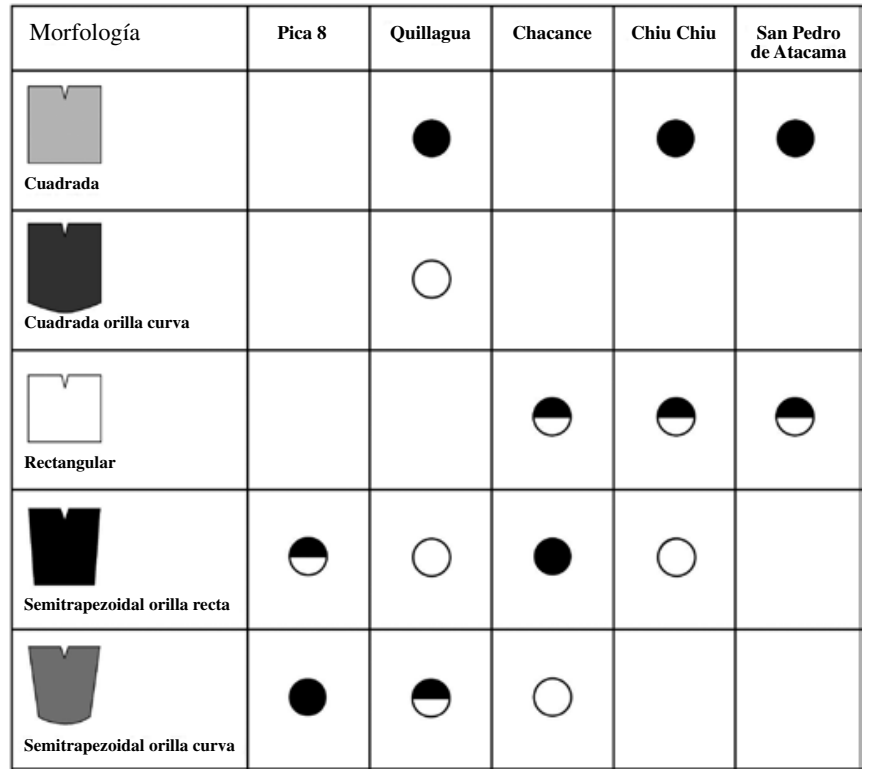


al 50\%, seguida por la semitrapezoidal de orilla de urdimbre recta $y$, en menor medida, con urdimbre curva (Agüero 2007). Cabe destacar que esta autora reporta dos túnicas "atípicas", es decir, cuadrangulares con orilla de urdimbre curva, que dan cuenta, a nivel formal, de la fusión de atributos textiles de Tarapacá y Atacama. Lo anterior complementa datos ya publicados que señalan la existencia de un estilo Loa-Tarapacá, que se distribuye fundamentalmente en los cementerios del curso inferior del Loa, caracterizándose por la mixtura de atributos decorativos y técnicos propios de las tradiciones textiles de Atacama y de Valles Occidentales (ref. Agüero 1998, Agüero 2007; Agüero et al. 1999).

Por su parte, en Chacance las túnicas semitrapezoidales de orilla de urdimbre recta son las más populares, seguidas de las rectangulares y las semitrapezoidales de orilla curva. Chiu Chiu, a su vez, muestra principalmente túnicas atacameñas, asignables al período Medio de San Pedro de Atacama o al período Intermedio Tardío, todas cuadradas a rectangulares (Agüero 2007). Sin embargo, la autora señala la existencia en Chiu Chiu de un fragmento de túnica trapezoidal, a la que se suma otra de orilla recta descrita por Boman (1992 [1908]:753, Fig. 189) y Montell (1926:17). Los oasis de Atacama, en cambio, destacan por las formas cuadrangulares o apenas rectangulares al ancho (Agüero et al. 1999). En todos los cementerios del río Loa que hemos señalado prevalecen las tramas múltiples, aunque el uso de trama única varía su representación en cada uno de ellos, marcando una diferencia con los cementerios de San Pedro de Atacama, donde sólo se registran tramas múltiples (Agüero 2007; Agüero et al. 1999).

De estos antecedentes es evidente en el Formativo la dificultad de adscribir las túnicas a una determinada región cultural, situación que, como veremos luego, se extiende a la representación parietal. En tanto, en el período Intermedio Tardío la forma general de la pieza permite reconocer con más facilidad túnicas de la región tarapaqueña y atacameña, destacando la mayor diversidad formal en las túnicas de la cuenca baja del Loa y de Quillagua en específico, en coherencia con su historia de interacción.

\section{El Vestuario en el Registro Rupestre de Atacama y Tarapacá}

En la secuencia rupestre de Atacama, cuenca del Loa, su afluente el río Salado y Salar de Atacama, los estilos arcaicos (Kalina y Puripica) son caracterizados fundamentalmente por grabados de camélidos, sin una contraparte antropomorfa. La figura humana sólo comienza a ser representada a partir del período Formativo Temprano y con ella también, tempranamente, la vestimenta. Durante este lapso, para el estilo Taira-Tulán se observan figuras antropomorfas grabadas con tocados, las cuales son escasas en comparación con el sobresaliente número de camélidos propios de este estilo. No hay prendas textiles reconocidas para el estilo Taira-Tulán. Sincrónicamente, en la subregión de río Salado, el estilo Confluencia exhibe pinturas de gran calidad en cuanto a su factura en las cuales las imágenes antropomorfas son comunes, muchas veces en composición escénica con camélidos. Ellas portan faldellines de pabilos colgantes, los cuales son representados mediante dispositivos de transparencia, solución que permite ver un plano anterior -faldellín- y uno posterior -las piernas de la figura.

Hacia el Formativo Tardío, quizás en transición desde el período anterior, estos faldellines segmentados (sensu Montt 2002b, 2004) también se presentan al sur del Salar de Atacama, mientras en río Salado se implementa otro patrón de representación humana, marcado por figuras esta vez frontales y estructuradas bajo un esquema de axialidad, sin asociaciones a camélidos y en composiciones que incluyen elementos geométricos, a la manera de un textil. Este es el estilo Cueva Blanca, en el cual las figuras antropomorfas continúan siendo vestidas con faldellines desdoblados (sensu Montt 2002b, 2004), bajo la norma de axialidad. En el Alto Loa, en cambio, grabados de figuras humanas frontales similares a la construcción de aquellas Cueva Blanca muestran por primera vez en la secuencia rupestre regional un tipo de vestuario de cuerpo completo y de lado cóncavo, que considera tanto el tórax como la pelvis de las figuras. Paralelamente, algunas figuras antropomorfas de la subregión de río Salado también dispuestas en frontalidad y axialidad, pero sin estilo definido para ellas, exhiben faldellines segmentados continuos (sensu Montt 2002b, 2004), cuyos pabilos son circunscritos por un perímetro, mientras otras están ataviadas por una vestimenta de área rectangular, situada también a la altura de la pelvis. Ésta fue nombrada en un principio como falda continua (sensu Montt 2002b, 2004) y en este artículo es definida como taparrabo. 
Hacia el final del período Formativo Tardío se observan en la subregión de río Salado algunos paneles rupestres en los cuales se aprecian seres antropomorfos con faldellines tipo segmentado continuo, adyacentes a figuras con "vestimentas" de lado cóncavo ${ }^{3}$. Otros paneles, muy cercanos a los anteriores, exhiben pinturas antropomorfas vestidas con taparrabo.

Avanzando en la secuencia rupestre, durante el período Intermedio Tardío se dejan de representar faldellines y el vestuario es, casi en su totalidad, de cuerpo completo (Montt 2002b, 2004, 2005). Discrepamos, entonces, con la propuesta de que el estilo Milla y sus túnicas pintadas de manera perimetral sean epigonales o residuales a Taira (Berenguer 1995, 1999). El vestuario, como recurso comunicativo, adquiere variabilidad no sólo en su forma, sino también en su decoración y cromática. La investigación propone, para el Alto Loa, la existencia del estilo Santa Bárbara I (990-1425 d.C.) y Santa Bárbara II (1300-1480 d.C.) (Berenguer 2002). El primero, consistente en grabados esquemáticos de camélidos, antropomorfos vestidos con túnicas realizadas arealmente y decoradas, además de una variedad de diseños de referente desconocido. En relación con el estilo Santa Bárbara II, Berenguer (2002) plantea que se trata de pinturas que incluyen colores como el rojo, amarillo, verde, negro, blanco, café y beige. Este estilo considera figuras humanas frontales, unos pocos camélidos de perfil y diseños geométricos. La figura humana es realizada de manera más esquemática, identificándosela como "escutiformes" (Aschero 2000; Berenguer 1999, 2002, 2004; Montt 2005) o personificaciones de hachas (Montt 2005; Montt y Pimentel 2009; Pimentel et al. 2007).

Se encuentren o no adscritas al estilo Santa Bárbara, a lo largo del período Intermedio Tardío en toda la región se identifican figuras antropomorfas vestidas con túnicas. Formando escenas de diverso tipo o bien solas, ellas se encuentran en espacios de quebradas asociadas, en ocasiones, a ocupaciones no aldeanas, siendo frecuente su presencia en áreas despobladas, funcionales sólo para la circulación de individuos y sus recuas.

En esta apretada caracterización de los principales estilos rupestres en Atacama y la puesta en secuencia de sus vestimentas asociadas, no podemos omitir los recientes estudios rupestres del complejo Pica-Tarapacá, período Intermedio Tardío, y el comportamiento que las vestimentas adquieren en este ámbito (Vilches y Cabello 2010, 2011). Siempre se trata de grabados realizados en asentamientos de carácter habitacional (Pokarqollu, Chusmiza, Jamajuga, Camiña-1 y Tarapacá Viejo), lo que determina una convivencia cercana de las poblaciones con sus imágenes. Los pocos faldellines que se hallan son del tipo desdoblado, y dentro de las túnicas destacan ejemplares triangulares (sensu Vilches y Cabello 2011) o trapezoidales con orillas de urdimbre curva, las que son vinculadas por las autoras, siguiendo a Agüero (2007), con la vestimenta del Complejo Pica-Tarapacá. Otros ejemplares son trapezoidales de base recta, a los que se suma una interesante variedad de túnicas rectangulares.

\section{Las Túnicas Pintadas del Loa}

Para los sectores alto y medio del río Loa se registran 89 sitios con pinturas, algunos de ellos ya reportados por Berenguer (1999, 2004 a y b, entre otros), conformando un universo de 326 paneles y 793 motivos simples, de los cuales sólo 59 corresponden a figuras antropomorfas vistiendo túnicas, distribuidas en 26 paneles y 19 sitios.

En las figuras humanas rupestres, las túnicas fueron pintadas en el área correspondiente al tronco, de modo areal (como superficie) o perimetral (como contorno). Estas prendas de vestimenta rupestre exhiben formas rectangulares, cuadradas, trapezoidales y de lado cóncavo. De acuerdo a los antecedentes textiles expuestos en la sección anterior, que operan como referentes para nuestra muestra de estudio, las dos primeras formas se vincularían con túnicas rectangulares y cuadradas, predominantes en la región atacameña. Asimismo, asociamos a las formas rupestres trapezoidales con las túnicas de Pica-Tarapacá, atendiendo los estrechos vínculos que Quillagua, en el Loa Inferior, presenta con dicho complejo cultural durante la primera parte del período Intermedio Tardío. Las vestimentas de lado cóncavo son identificadas en el registro parietal del Alto Loa y subregión de río Salado a partir del período Formativo Tardío, en su momento de transición hacia el período Intermedio Tardío (Montt 2005), siendo un tipo de representación que, a la fecha, no cuenta con referentes claros. Otras representaciones de vestimenta son aquellas denominadas usualmente como escutiformes ${ }^{4}$, las que han sido identificadas por nosotros como personificaciones de hachas (Montt 2005; Montt y Pimentel 2009). Es necesario a futuro contrastar el 
que las vestimentas de lado cóncavo correspondan también a esta categoría.

Para precisar la diversidad existente, diferenciamos la forma rectangular de la cuadrangular, de acuerdo a las dimensiones de alto y ancho tanto de las túnicas textiles como parietales. Esta proporcionalidad nos parece relevante, ya que observamos, en este sentido, una coherencia entre la variabilidad textil y la pintada. Para efectos del análisis, incluimos la forma subrectangular, reuniendo en ella ejemplares romboidales y trapezoidales invertidos, todos excepcionales y para los cuales no contamos con referentes textiles (Pimentel y Montt 2008:47, Figs. 14 y 15; Figura 6). Asimismo, incluimos en el análisis la forma de la orilla inferior de las túnicas pintadas, pues, como vimos anteriormente, en esta prenda textil opera como un diacrítico relevante en combinación con la morfología. Por su parte, las

(a)

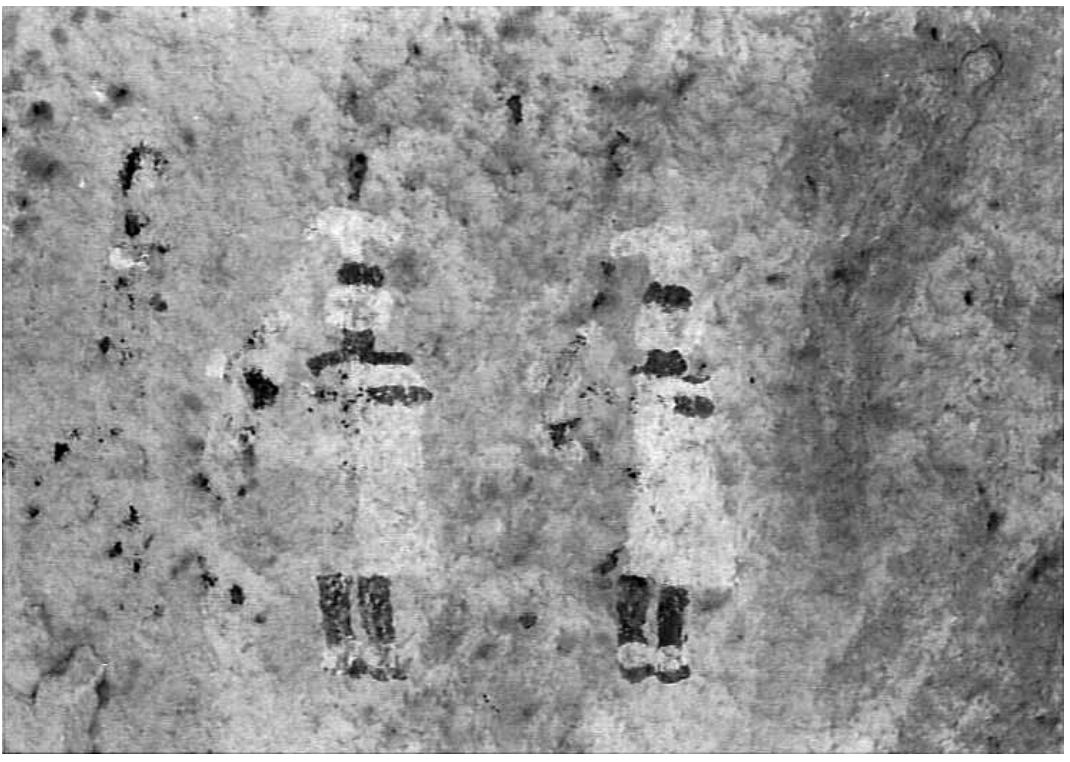

(b)

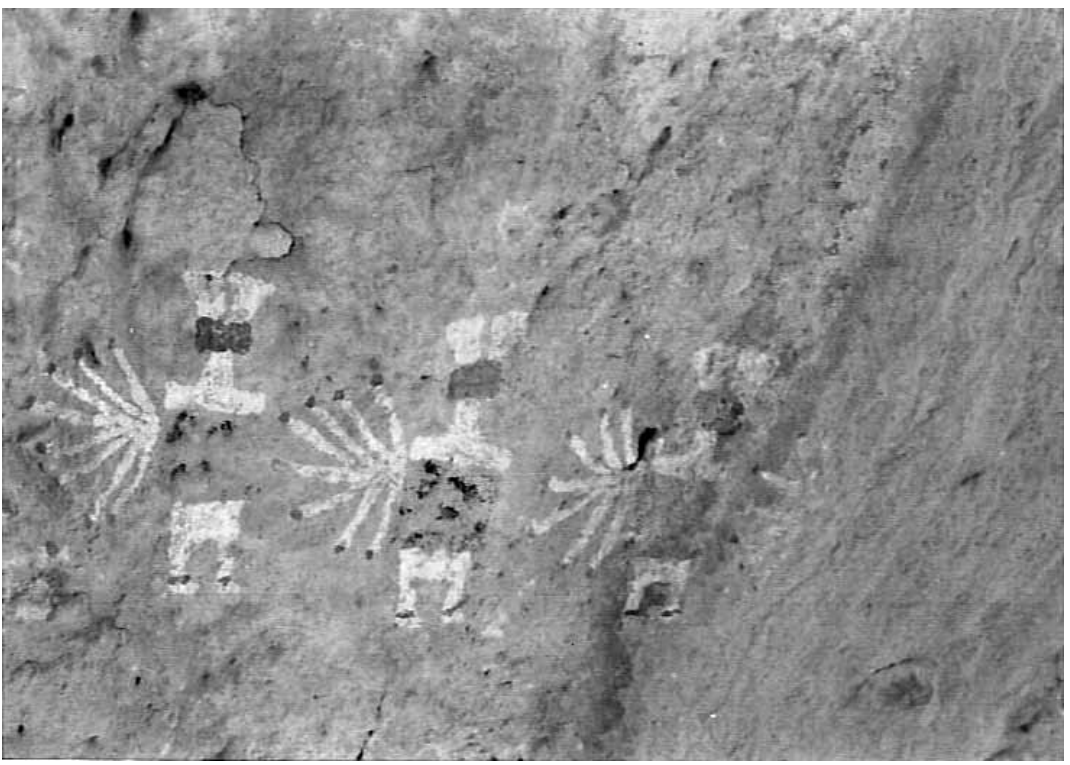

Figura 6. Túnicas subrectangulares del sitio San Salvador 1 en el Loa Medio: (a) trapezoidal invertida (h máx. 160 mm); (b) subrectangular con taparrabo (h máx. $150 \mathrm{~mm}$ ).

Subrectangular tunics from San Salvador 1, Middle Loa Basin: (a) inverted trapezoid (h. max. 160 mm); (b) subrectangular with loincloth (h. max. $150 \mathrm{~mm}$ ). 
vestimentas de lado cóncavo, independientemente de si sus referentes sean o no un textil, son una forma presente también en los geoglifos de Arica y Tarapacá (Núñez 1976), siendo adscritas al estilo Pintados de tradición tarapaqueña (Briones 2006). Destacamos la presencia de taparrabos como otro elemento de atuendo rupestre, inicialmente denominado por Montt (2002b) como falda. Se trata de una forma rectangular situada en la parte inferior de la figura humana, realizada habitualmente en el mismo color que el resto del motivo antropomorfo, presentándose en las pinturas del Loa Medio en combinación con túnicas, sobre un mismo cuerpo (ver Figuras $6 \mathrm{~b}$ y $11 \mathrm{a}, \mathrm{b}$ y c).

En el caso de las túnicas, la combinatoria de formas y orillas generó una amplia tipología de vestimenta rupestre, de la cual sólo cinco tipos corresponden a referentes conocidos en el dominio textil, ya que hasta ahora no se cuenta con registros de formas rectangulares de orilla curva (Tabla 3 ).

Las túnicas pintadas suelen ser rojas, de forma rectangular con orilla recta, de altura mayor al ancho, de tamaño variable, a pesar de ciertas particularidades del sector medio y alto del río Loa, a las que nos referiremos a continuación. Para esta forma, sin embargo, es difícil aventurar una adscripción cronológica precisa, pues podría corresponder tanto al Formativo como al Intermedio Tardío.

\section{Túnicas Pintadas en el Alto Loa}

En este sector las túnicas destacan por sus grandes dimensiones, entre 300 y $800 \mathrm{~mm}$ de alto y 150 a $500 \mathrm{~mm}$ de ancho. Este tramo del Loa muestra una variedad morfológica discreta, con túnicas realizadas mediante la combinación perimetral y areal (estilo Santa Bárbara II) (Berenguer 1999, 2004 a y b) y perimetral lineal (estilo Milla) (Berenguer 1999, 2004a). El Alto Loa comparte sólo tres formas con el Loa Medio: rectangular con orilla curva, rectangular de orilla recta y trapezoidal con orilla recta. De éstas, dos cuentan con referentes textiles conocidos, en vinculación a Tarapacá y Atacama (Tabla 3).

Entre las túnicas rectangulares queremos señalar un panel ampliamente citado, que vincula los estilos La Isla de este sector y Cueva Blanca del río Salado, con túnicas tejidas Alto Ramírez provenientes de los valles de Azapa y Camarones (Horta 2004). Éstas reproducen en la parte inferior un rostro frontal radiado en técnica de tapicería en una configuración casi idéntica a su soporte parietal (Berenguer 1999:33, 2004b:88, Fig. 12 a y b; Horta y Berenguer 1995). Consideramos este motivo antropomorfo con túnica, porque, de acuerdo a nuestras observaciones en terreno, tiene extremidades inferiores y posiblemente un tocado

Tabla 3. Síntesis de las túnicas rupestres, por sector. Con asterisco las formas con referentes en el dominio textil. Summary of rock art tunics in each area. Asterisks indicate the forms with counterparts in the textile domain.

\begin{tabular}{|c|c|c|c|}
\hline & & Loa Medio & Alto Loa \\
\hline & Total Motivos simples & 38 & 21 \\
\hline \multirow{15}{*}{ Morfología } & de lado cóncavo con orilla curva & & 4 \\
\hline & de lado cóncavo con orilla recta & 5 & \\
\hline & de lado cóncavo $\mathrm{n} / \mathrm{r}$ & & 1 \\
\hline & cuadrado con orilla curva* & 1 & \\
\hline & personificación de hacha con orilla curva & & 3 \\
\hline & personificación de hacha $\mathrm{n} / \mathrm{r}$ & 1 & \\
\hline & ovoidal con orilla curva & & 2 \\
\hline & ovoidal con orilla recta & & 1 \\
\hline & rectangular con flecadura* & 1 & \\
\hline & rectangular con orilla curva & 1 & 2 \\
\hline & rectangular con orilla recta* & 14 & 5 \\
\hline & subrectangular con orilla curva & 4 & \\
\hline & subrectangular con orilla recta & 6 & \\
\hline & trapezoidal con orilla curva & 1 & \\
\hline & trapezoidal con orilla recta* & 3 & 3 \\
\hline \multirow{2}{*}{ Taparrabo } & Ausencia & 19 & 21 \\
\hline & Presencia & 19 & \\
\hline
\end{tabular}


(Figura 7a). Reiteramos que las túnicas textiles a las que se vincula de acuerdo a la iconografía corresponden sólo a tres ejemplares fragmentados (Horta 2004) (Figura 7b). Sin embargo, este pequeño conjunto se integra en un grupo de túnicas que cuenta con una amplia distribución entre Azapa y el Loa Medio (Agüero y Cases 2004).

Nos parece relevante destacar que la orilla curva, un atributo tarapaqueño dentro del repertorio textil del Intermedio Tardío, sea característica de este sector del Loa. Asimismo, que la orilla curva coexista con formas de lado cóncavo en una misma figura rupestre, ya que de acuerdo a Montt (2005) serían transicionales tanto en el reemplazo de faldellines por túnicas como en su situación cronológica, entre el final del Formativo y los inicios del Período Intermedio Tardío, época en que se vislumbra más claramente una situación de convivencia en Quillagua.

(a)
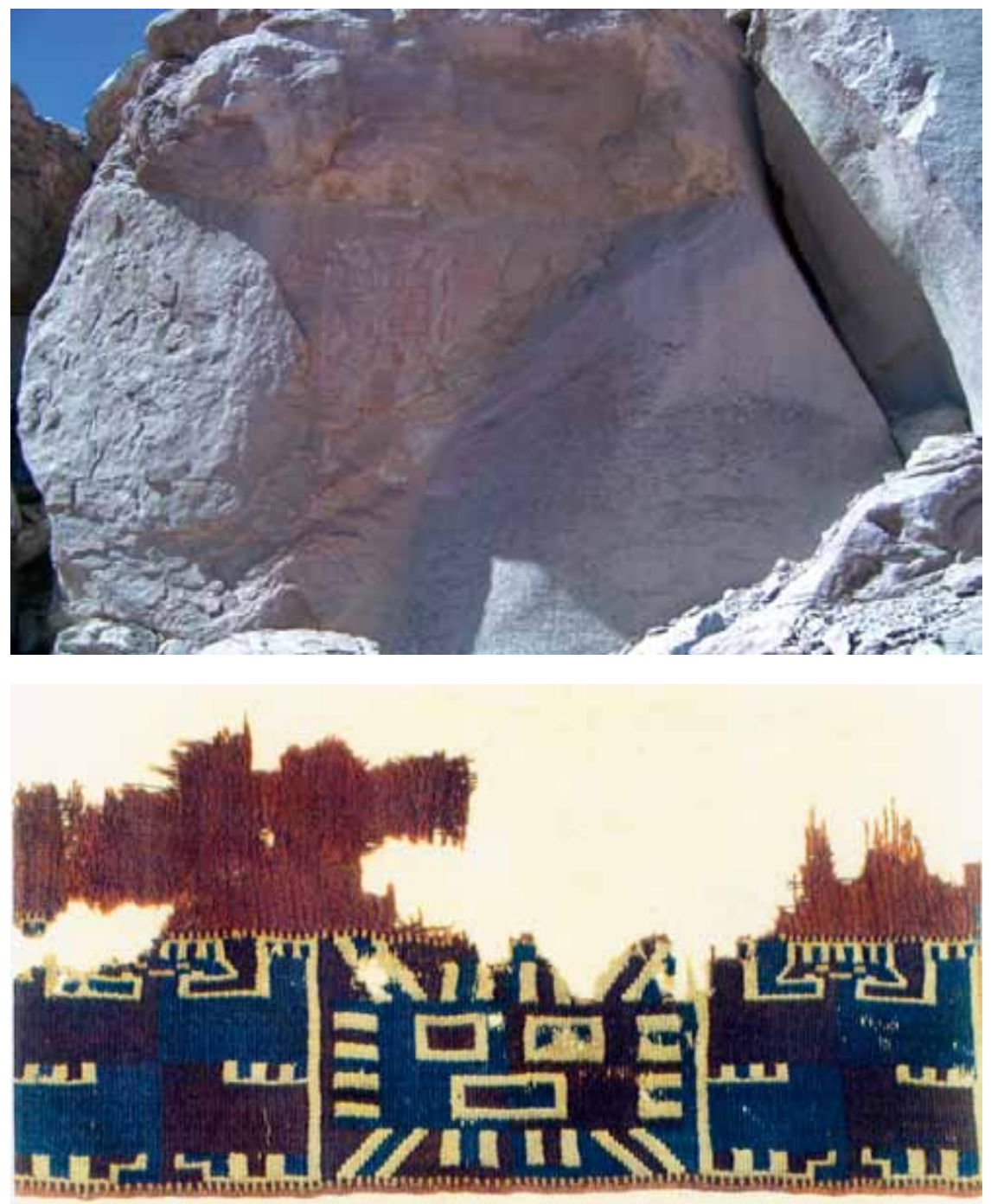

(b)

Figura 7. (a) Túnica rectangular alta, con rostro radiado del sitio La Isla o LS075, alto Loa, en que se observan extremidades inferiores y tocado (h máx. $1.100 \mathrm{~mm}$ ) y (b) túnica fragmentada de Azapa 70, s/ref (Agüero y Cases 2000).

(a) Rectangular tunic, with radiated face from La Isla or LS075, site, Upper Loa, with depiction of lower extremities and headdress, (h. max. 1,100 mm) and (b) fragmented tunic from Azapa 70, no ref (Agüero and Cases 2000). 
También resulta interesante que figuras presentes en los geoglifos de Pintados, pero con orilla recta (Briones 2006:17, Fig. 6; Figura 8), se encuentren también en el Alto Loa, específicamente en un panel del sitio Taira, constituyendo uno de los pocos motivos compuestos del sector (Figura 9). Se trata de seis figuras humanas pintadas por medio de un trazo continuo en color rojo, bajo el vientre y entre las patas de un camélido de factura más temprana (Horta 2000) (Estilo Taira-Tulán), que enmarca los motivos (Berenguer 1999:23; 2004b:83, Fig. 7) ${ }^{5}$.

Cabe destacar que las túnicas pintadas de Santa Bárbara 110, a partir de las cuales se define el Estilo Santa Bárbara II (1.300 a 1.500 d.C.) (Berenguer et al. 1985), ya han sido vinculadas con tejidos semitrapezoidales tarapaqueños y, más específicamente, en sus variantes teñidas por amarras (Berenguer 1999:45-6, 2004b:95, Fig. 19 y Montt 2005, respectivamente). Estas túnicas textiles, desde un punto vista técnico son tarapaqueñas y se adscriben al período Intermedio Tardío inicial (Cases y Agüero 2004:126, Fig. 7; Figura 10), lo cual abre la posibilidad que este estilo sea más temprano o que no sea este tipo de túnica lo que se pintó.

\section{Túnicas Pintadas en el Loa Medio}

A diferencia de los sectores altos, en el Loa Medio existe la representación rupestre de taparrabo como indumentaria, observándose también tobilleras y elementos radiados dispuestos en forma adyacente al tercio superior del cuerpo (Pimentel y Montt 2008:44, 46-47, Figs. 13 y 15. Ver Figura 6b). Las túnicas son de dimensiones muy inferiores, de hasta $200 \mathrm{~mm}$ de alto por $100 \mathrm{~mm}$ de ancho. Con frecuencia las túnicas se pintaron de manera areal en color rojo, blanco y/o negro. Existen pocos motivos logrados por un perímetro lineal y una sola túnica con decoración interior.

Aquí cabe destacar la mayor diversidad formal, lo que nos recuerda lo observado en los tejidos de los cementerios del Loa Inferior: una mayor variabilidad en cuanto a la combinatoria de formas de túnica y orillas de urdimbre. Luego sobresale la frecuencia que tienen las túnicas subrectangulares, independiente del tipo de orilla (Figura 11a y b). Las formas rupestres de lado cóncavo son una de las pocas compartidas con el Alto Loa que, como ya señalamos, se asemeja a su contraparte del estilo Pintados (Figura 11c y d). Lo anterior, con la salvedad de que estas formas de lado cóncavo presentan orilla recta. Para ambas formas, las subrectangulares y las de lado cóncavo, es difícil establecer un referente de vestuario y estas últimas, de acuerdo a Montt (2005), serían transicionales, lo que se confirmaría en su recurrente asociación a pinturas de taparrabos, marcando simultáneamente una diferencia con el Alto Loa, donde no se constata tal relación. Aquellas representaciones rectangulares ubicadas en el área baja del tronco en las figuras antropomorfas son, como ya se señaló, interpretadas como taparrabos, los que en uso y desde una vista frontal se observarían de la misma forma (Sinclaire 1997; Berenguer 1999 y 2004b; Gallardo et al. 1999: 68; Figura 12 a). Tales taparrabos, similares a los que se relacionan con el estilo Cueva Blanca y $\mathrm{La}$ Isla, están bien caracterizados a partir de Topater, Chorrillos y San Salvador en el Loa Medio, donde se concentran (Agüero y Cases 2004). Nos parece importante destacar que en Topater encontramos un taparrabo de este tipo, cosido a una túnica formativa tardía del mismo grupo en el que se insertan aquellas que vinculan al Alto Loa con Arica y Camarones (Cases 2002). Asimismo, en el sitio San Lorenzo, en los alrededores del Salar de Atacama, se registró una figura antropomorfa que viste uno de estos taparrabos, confirmando al referente textil propuesto (Figura 12 b y c). Además, Boman describe una espátula de madera recuperada en Calama por Sénéchal de la Grange (1992 [1909]:737), con una figura humana que, de acuerdo al autor, vestiría dos túnicas: la inferior de altura mayor a la superior y una manta o aguayo (Figura 13). Cabe señalar que la superposición de túnicas en número de dos o tres está bien documentada en Quillagua en el Intermedio Tardío, como en otros cementerios prehispánicos, práctica que suponíamos asociada sólo a ámbitos funerarios. En tanto, el arte rupestre y la espátula ilustrada por Boman nos podrían indicar que esta disposición se extendería más allá de la funebria, posiblemente a ámbitos cotidianos, en los cuales se combinarían también distintos tipos de prenda.

Aunque no son frecuentes en el repertorio rupestre del Loa Medio, queremos llamar la atención hacia tres túnicas particulares. La primera es cuadrada de orilla curva, cuyo referente textil está en Quillagua (Agüero 2007), mezclando atributos formales de Atacama y Tarapacá; esta representación parietal además está en asociación a un taparrabo (Figura 14 a y b). La segunda, una túnica trapezoidal de orilla recta (Figura $14 \mathrm{c}$ ), que se asemeja a un motivo de Ariquilda 1 en la Quebrada de Aroma en la región de 


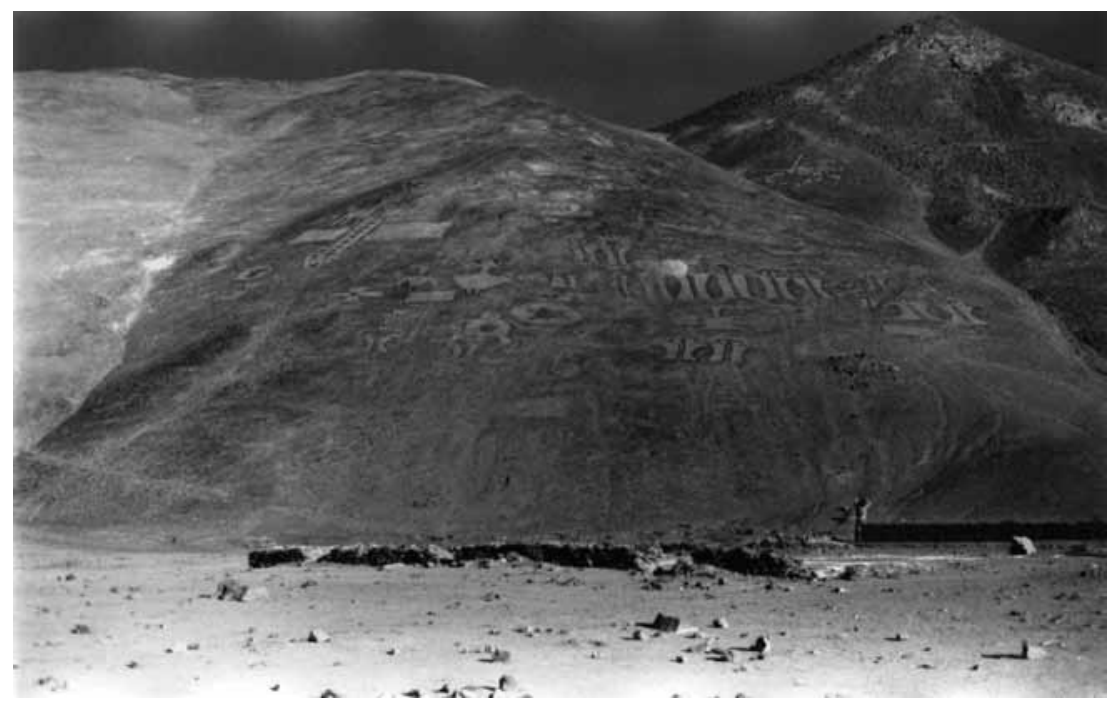

Figura 8. Geoglifos de Pintados, con túnicas de lado cóncavo.

Pintados geoglyphs with concave sided tunics.
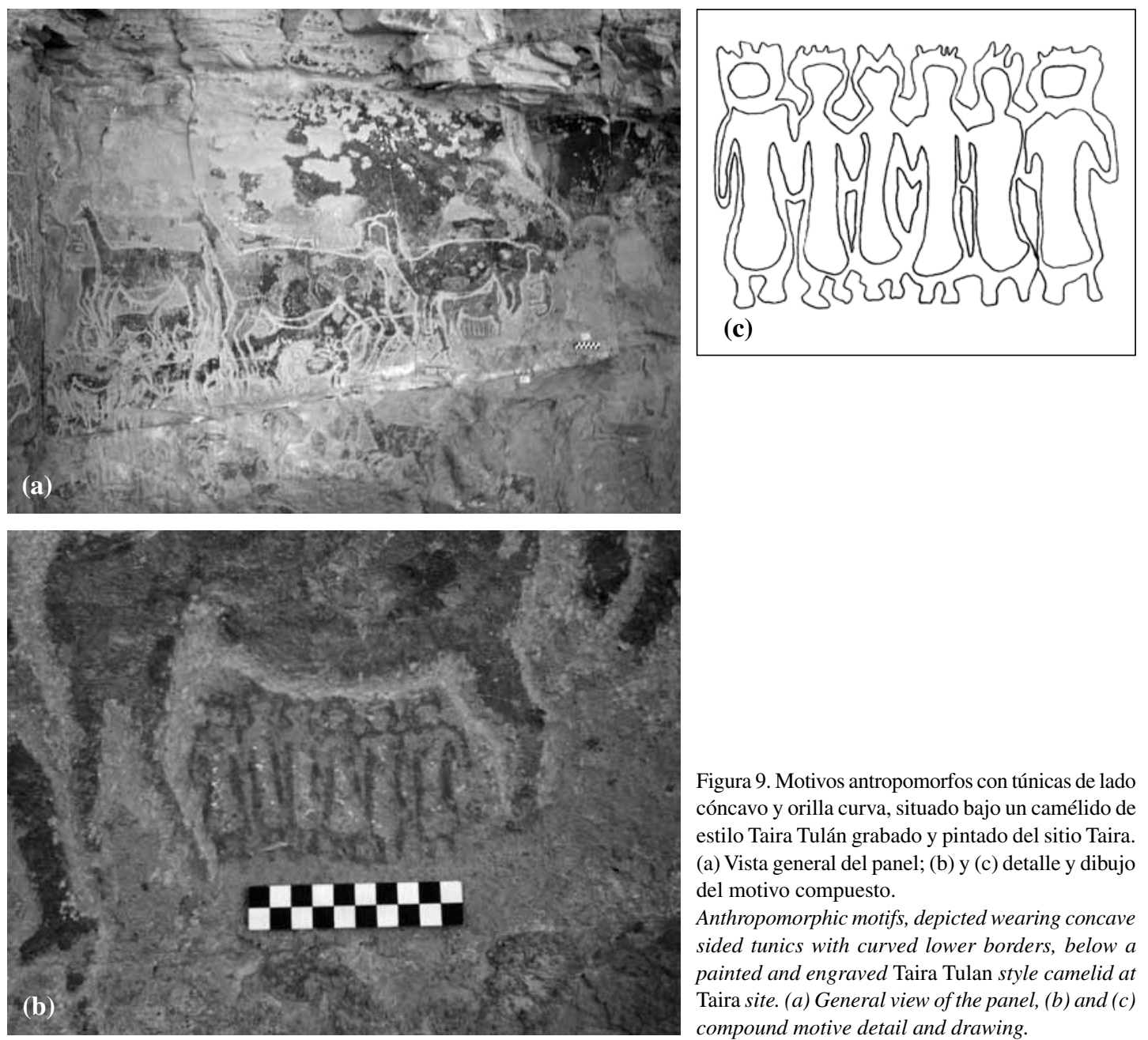

Figura 9. Motivos antropomorfos con túnicas de lado cóncavo y orilla curva, situado bajo un camélido de estilo Taira Tulán grabado y pintado del sitio Taira. (a) Vista general del panel; (b) y (c) detalle y dibujo del motivo compuesto.

Anthropomorphic motifs, depicted wearing concave sided tunics with curved lower borders, below a painted and engraved Taira Tulan style camelid at Taira site. (a) General view of the panel, (b) and (c) compound motive detail and drawing. 

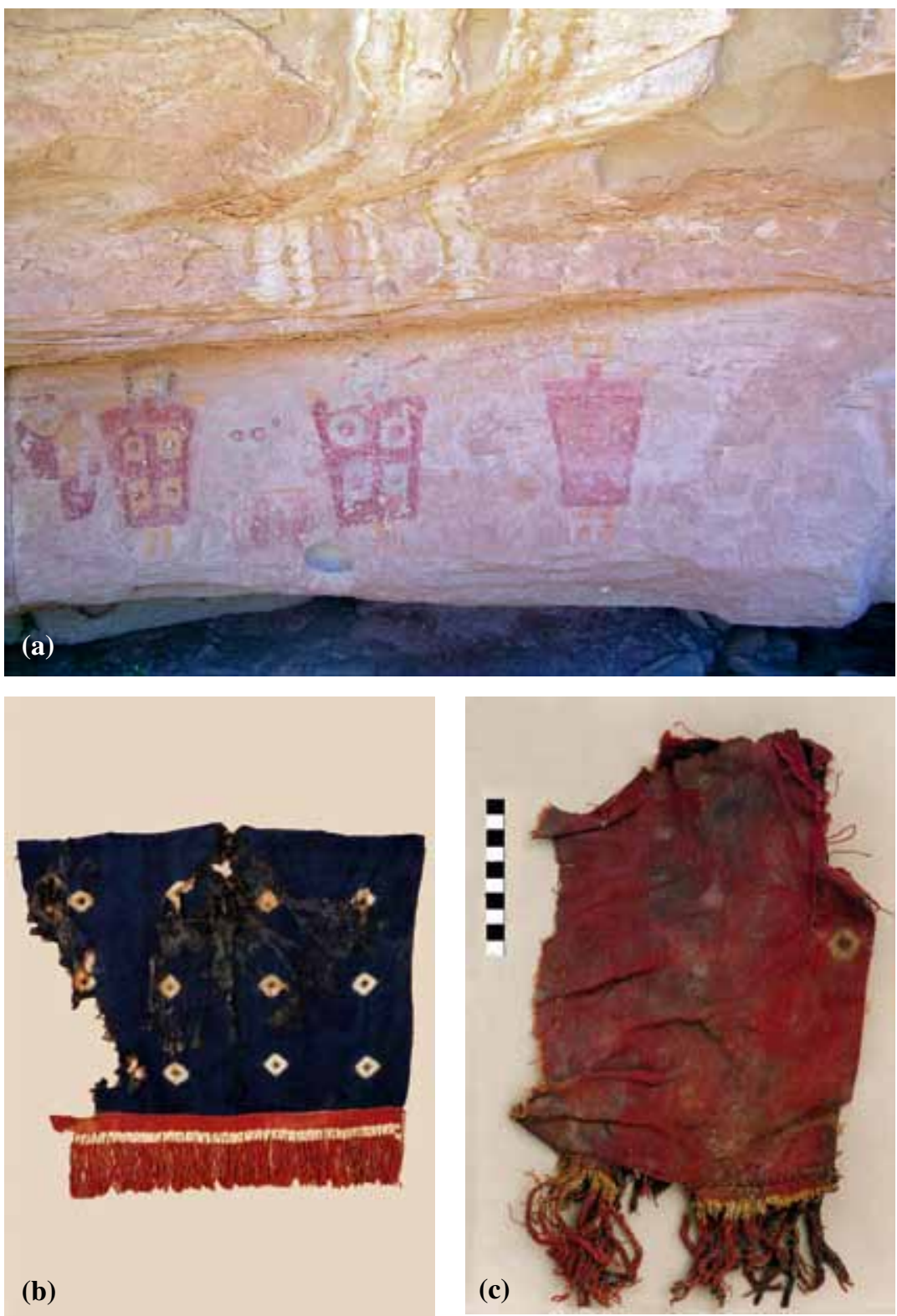

Figura 10. (a) Túnicas (semi)trapezoidales de orilla recta de Santa Bárbara (LS-77) (h máx. motivos 740 mm); (b y c) sus posibles referentes textiles de Tarapacá (Cases y Agüero 2004).

(a) (Semi) trapezoidal tunics with straight lower border from Santa Barbara (LS-77) (motifs h. max. 740 mm); (b, c) their possible textile referents from Tarapacá (Cases and Agüero 2004).

Tarapacá (Chacama y Espinoza 2005 [1999], Fig. 9f). La tercera, es de forma trapezoidal de orilla curva (Pimentel y Montt 2008: 45, Fig. 12; Figura 15 a), que indudablemente alude a su contraparte textil. Este motivo se asemeja a un motivo grabado del sitio habitacional de Jamajuga en la región de Tarapacá, para el cual Vilches y Cabello (2010:675, Fig. 2b) también establecen la relación con este tipo de túnicas (Figura 15 b). De acuerdo a las autoras, dicho sitio pertenece al período Intermedio Tardío, pero tiene un carácter más altiplánico y tardío, en asociación a una arquitectura que se acerca a las ocupaciones contemporáneas de las quebradas del Loa Superior y San Pedro de Atacama. 

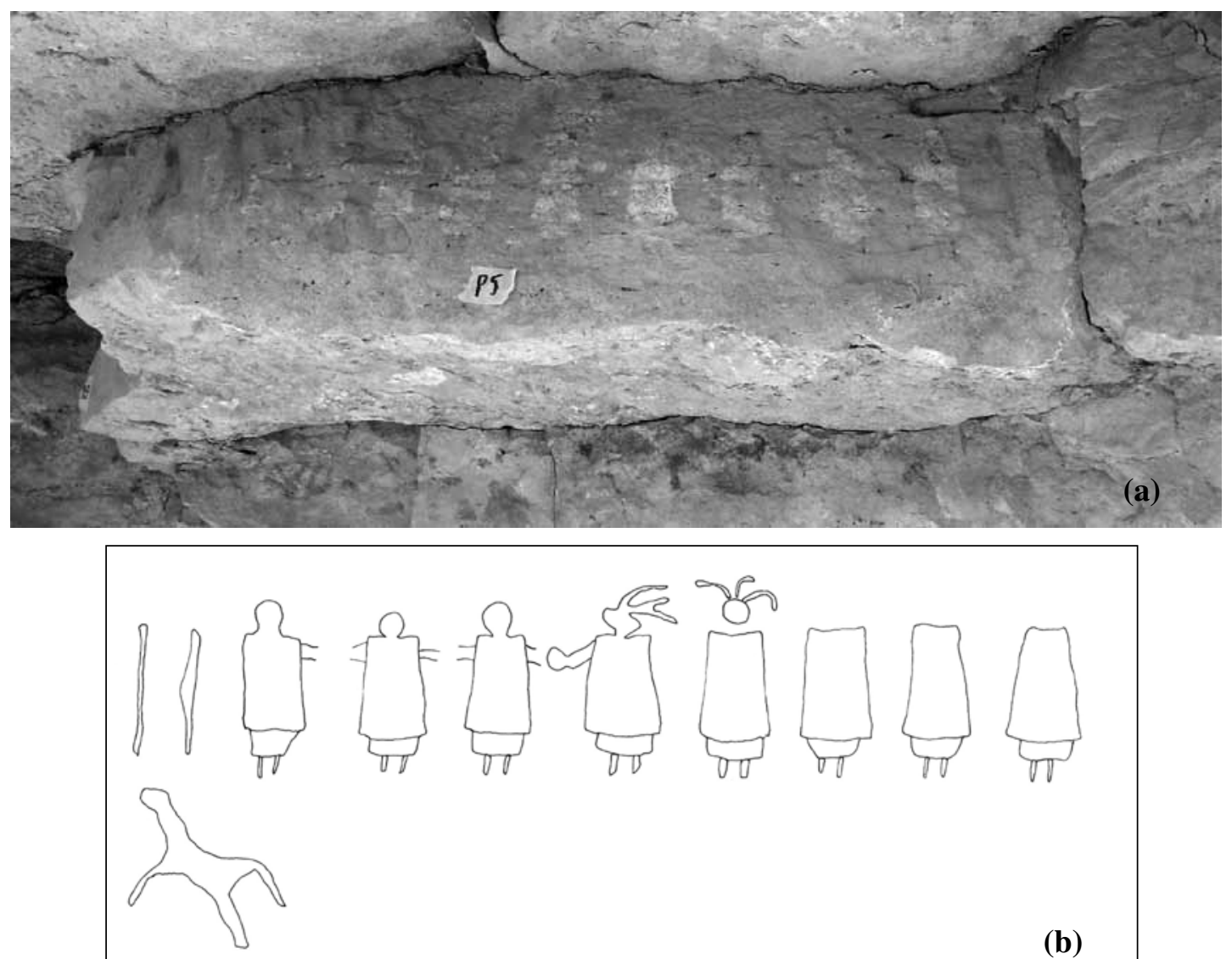

(b)
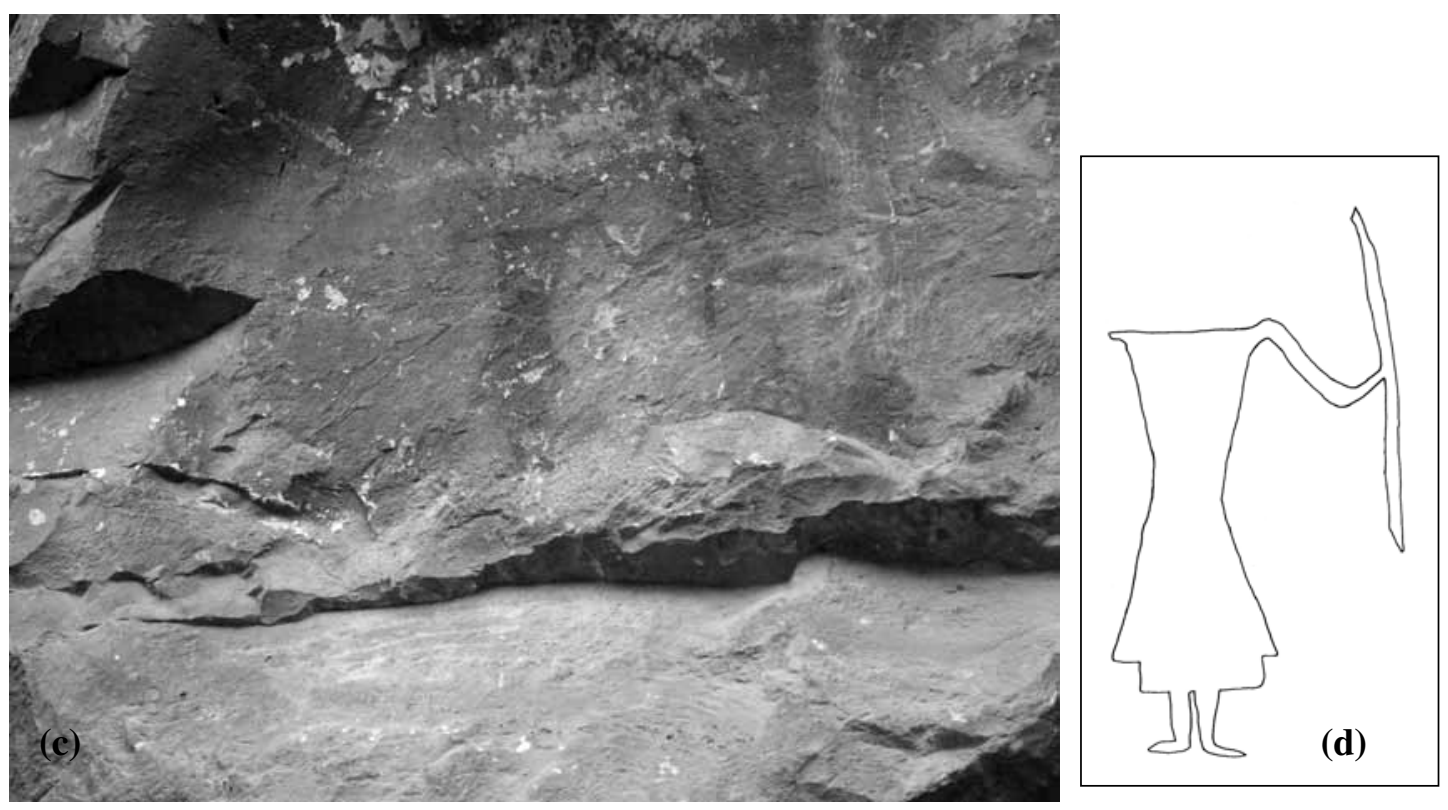

Figura 11. Túnicas del Loa Medio: (a) y (b) subrectangulares con taparrabo, Ojos de Opache (LM03), río San Salvador (h máx. $120 \mathrm{~mm}$ ); (c) y (d) de lado cóncavo con taparrabo, Yalquincha (LM01), norte de Calama (h máx. $200 \mathrm{~mm}$ ).

Tunics from the middle Loa basin: (a), (b) subrectangular with loincloth, Ojos de Opache (LM03), San Salvador river (h. max. $120 \mathrm{~mm}) ;(\mathrm{c}),(\mathrm{d})$ concave sided with loincloth, Yalquincha (LM01) (h. max. $200 \mathrm{~mm}$ ). 

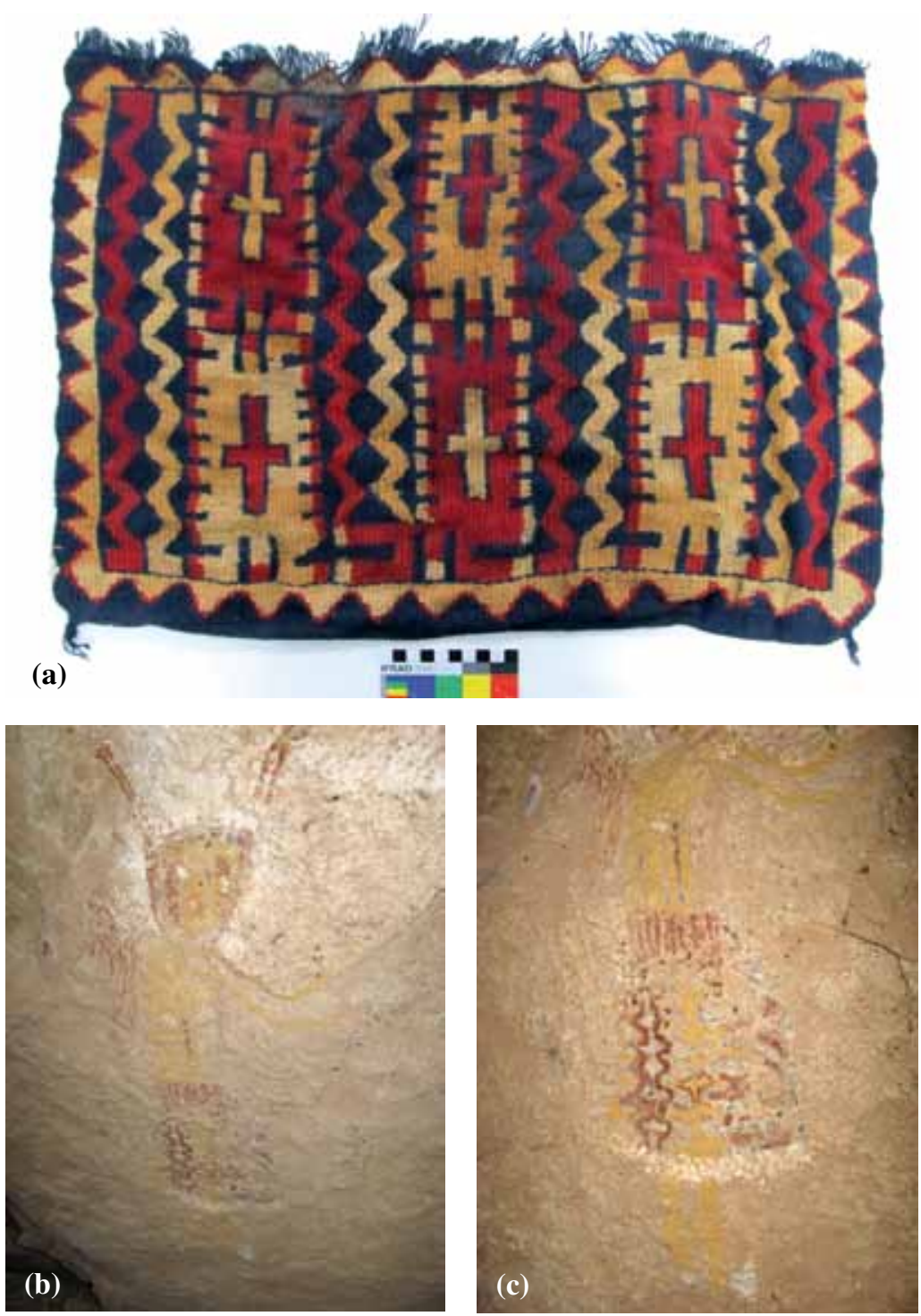

Figura 12. (a) Taparrabo del cementerio de Topater; (b) Figura antropomorfa con taparrabo del sitio Cueva San Lorenzo, Salar de Atacama (h máx. $500 \mathrm{~mm}$ ) y (c) detalle del taparrabo.

(a) loincloth from Topater cemetery; (b) anthropomorphic figure wearing loincloth, from San Lorenzo Cave, Salar de Atacama (h. $\max .500 \mathrm{~mm}$ ), and (c) loincloth detail.

En suma, las túnicas que visten algunas de las figuras antropomorfas pintadas del Loa Medio y Alto dejan en evidencia la combinación de rasgos formales de las túnicas y sus orillas de urdimbre. Estos atributos son verificados también en el registro textil de los cementerios del Loa Inferior y Medio, siendo paradigmático, en este sentido, el comportamiento de las túnicas recuperadas en Quillagua.

\section{Indumentaria y Túnicas Rupestres}

Si nos remontamos al Formativo Temprano, la representación rupestre de la indumentaria en la región atacameña, al menos en río Salado y el Salar de Atacama, consta principalmente de faldellines, representados como pabilos que penden de la cintura de la figura antropomorfa, dejando entrever sus piernas mediante un efecto de transparencia 

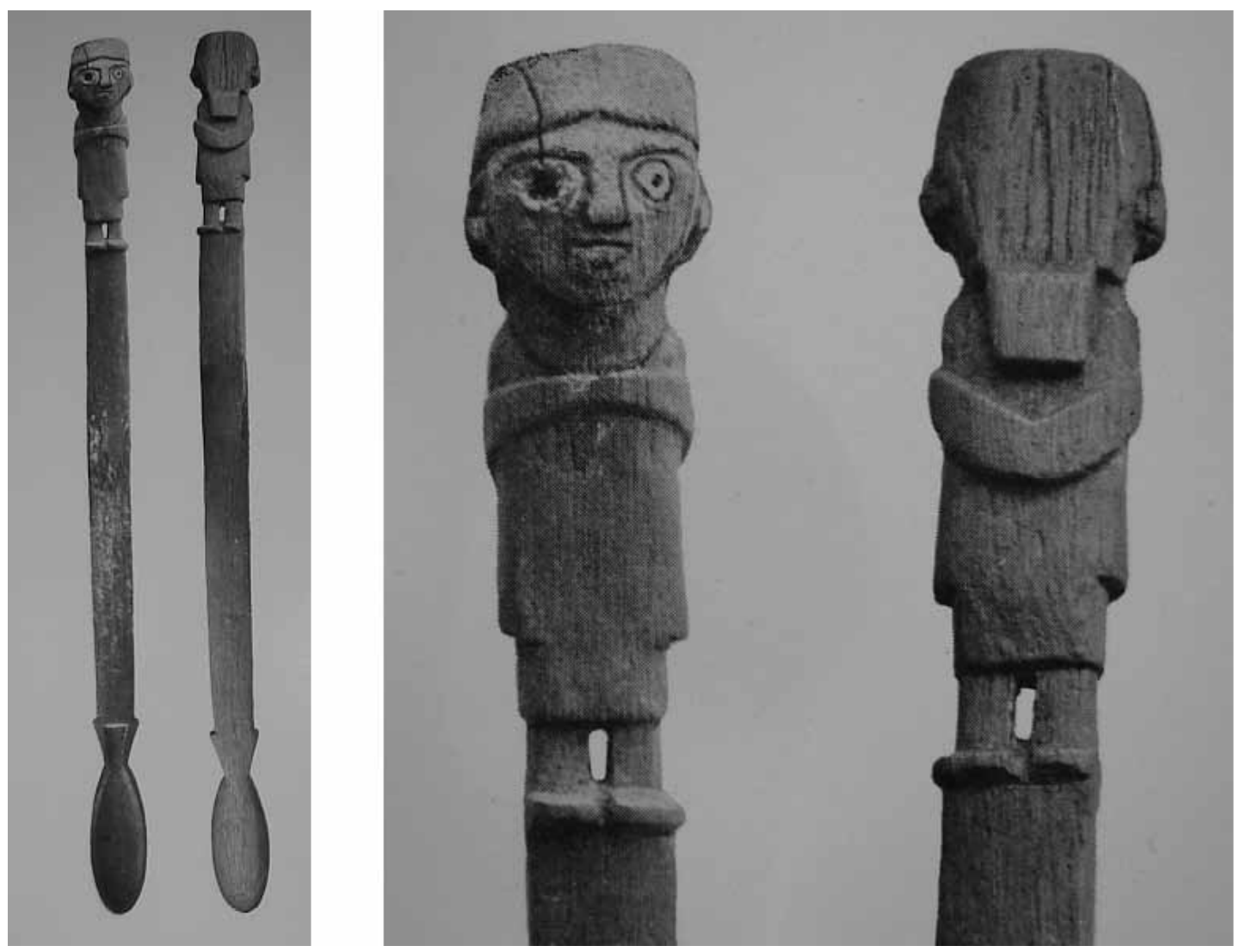

Figura 13. Espátula de madera descrita por Boman (1992 [1908]) con superposición de prendas. Wooden spoon described by Boman (1992 [1908]) with garment superposition.

(Montt 2005). La representación de estas prendas parece ser un fenómeno circunscrito, ya que no han sido registradas pinturas similares en todo el resto del curso del río Loa. Contemporáneamente, pocos faldellines textiles se registran en el cementerio de Topater, en el Loa Medio, en contextos sincrónicos de los Valles Occidentales como Camarones-15 y, posiblemente, Tarapacá- $40^{6}$. Además, en los sitios de funebria contemporáneos de la región se encuentran otros textiles como mantas y túnicas.

Durante el Formativo Tardío, en las mismas áreas que para el período anterior, más contados casos presentes en el Loa Medio y Alto, se observa un registro rupestre que continúa con la representación de faldellines. Esta vez son facturados de manera distinta, ya sea con los pabilos estructurados en axialidad (Figura 16) o con ellos circunscritos por un perímetro (Montt 2002b, 2004, 2005). Se suman a la representación de faldellines otras prendas de cuerpo completo, cuyos lados son cóncavos, para las cuales aún no se identifican referentes, como también taparrabos ${ }^{7}$. Éstos han sido hallados igualmente en el Loa Medio y son facturados en su totalidad mediante pintura, como una superficie cuadrangular a la altura de la pelvis de la figura. En este período, en los cementerios de la región se encuentran individuos vestidos con mantas, túnicas y taparrabos.

Observamos que la técnica textil de tapicería en que se confeccionaron los taparrabos relacionados al estilo rupestre Cueva Blanca y las bandas inferiores de algunas túnicas Alto Ramírez parecen traspasar la rigidez que la técnica textil demanda a la pintura rupestre. No sólo se trasponen en la pintura motivos que están en los textiles, los que podrían replicarse de un modo más "libre" por medio de la pintura, sino que los artistas pintaron como si estuvieran tejiendo una tapicería, en cierto modo replicando el cruce ortogonal de los hilados de trama por sobre los de urdimbre, tal como señalara Sinclaire (1997). La figura humana aparece en una composición que casi necesariamente apela a los 

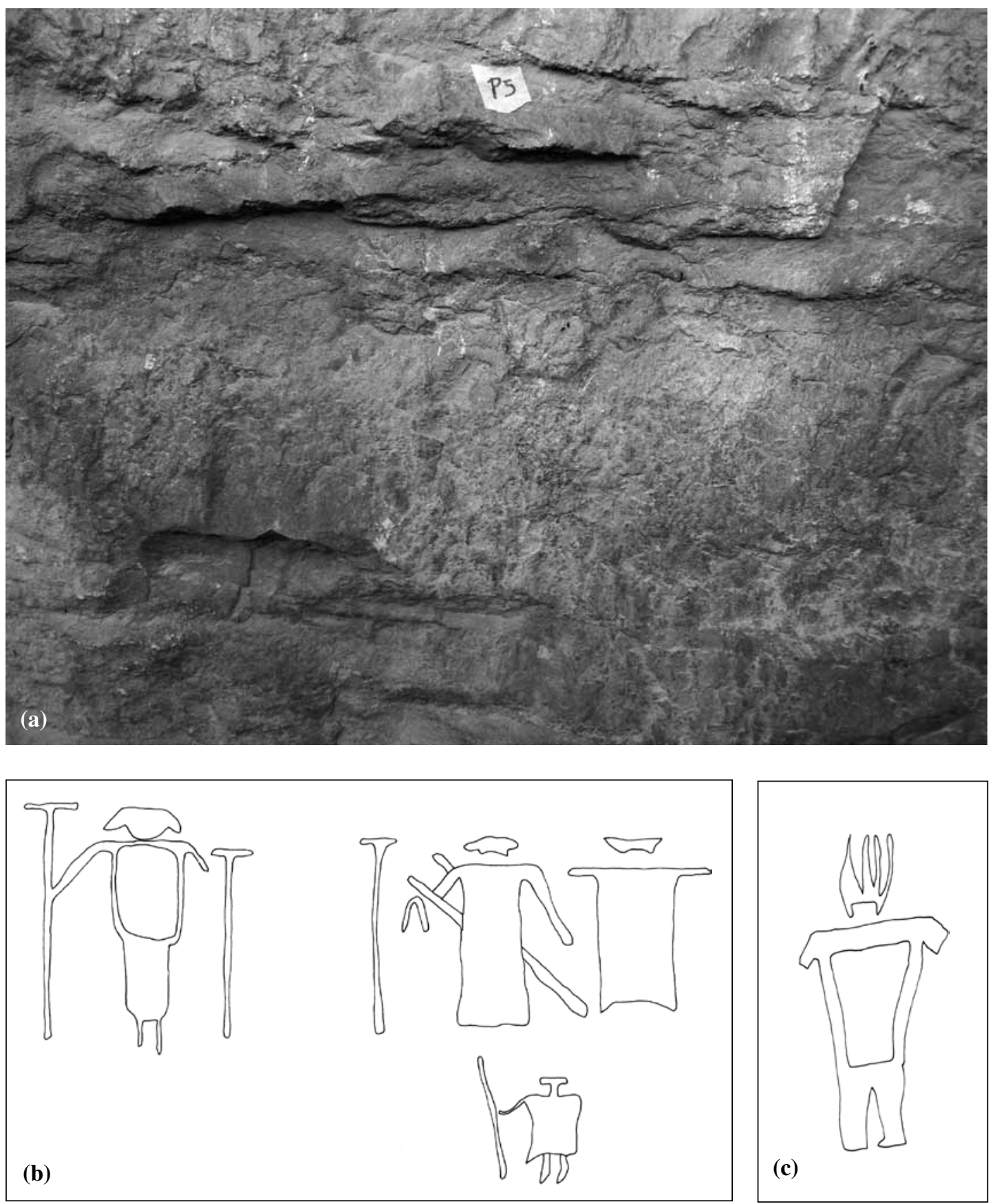

Figura 14. Túnicas del Loa Medio: (a y b) cuadrada de orilla curva con taparrabo, Yalquincha (h máx. 190 mm); (c) trapezoidal de orilla recta, Ojos de Opache (h máx. $200 \mathrm{~mm}$ ).

Tunics from the middle Loa basin: $(a, b)$ square with curved border and loincloth, Yalquincha ( $h$ max. 190 mm); (c) trapezoidal with straight border, Ojos de Opache ( $h$ max. $200 \mathrm{~mm}$ ). 

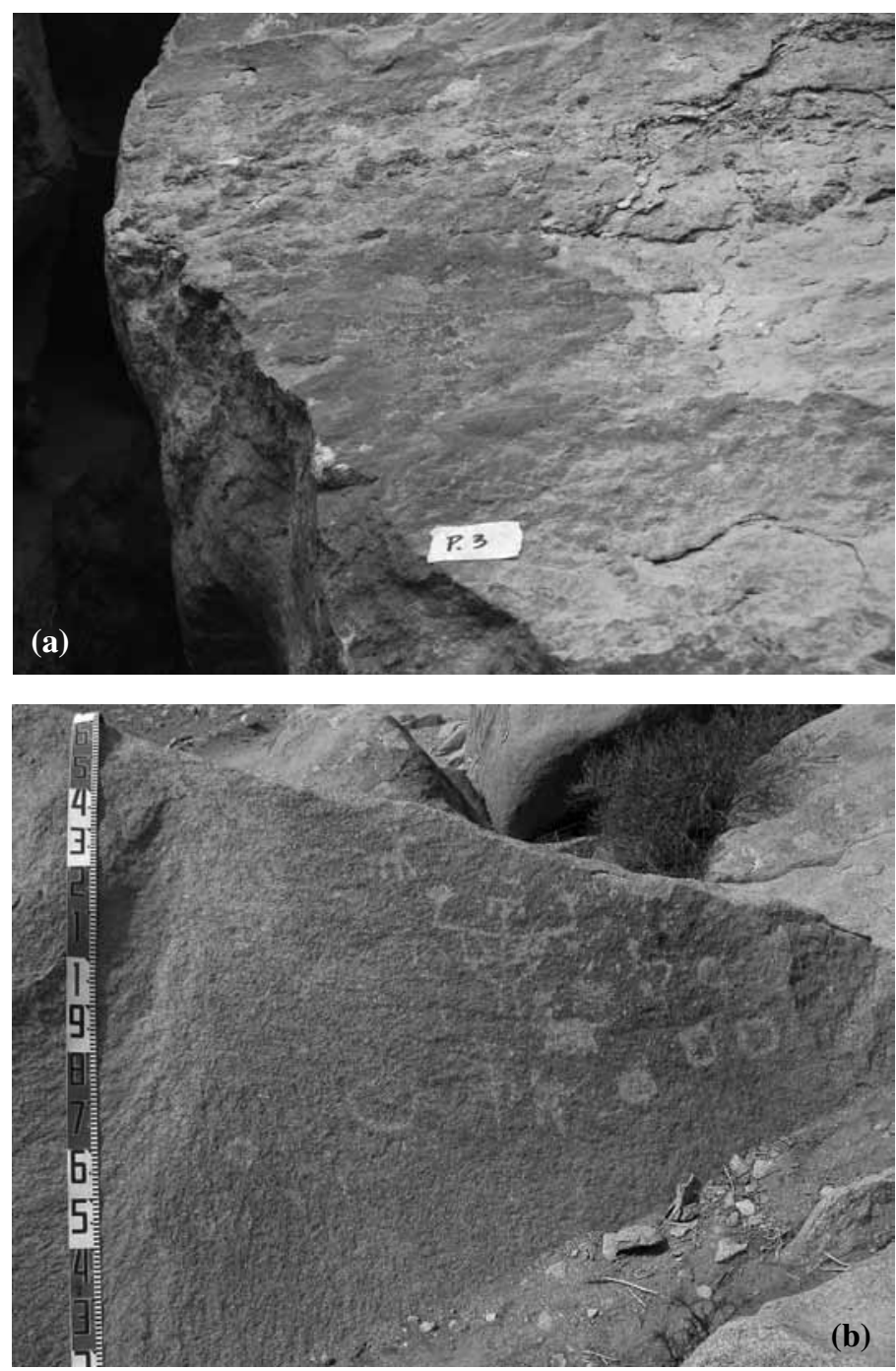

Figura 15. Túnica trapezoidal de orilla curva: (a) del sitio Yalquincha (LM01), Loa Medio (h máx. 180 mm) y (b) antropomorfo complejo del sitio Jamajuga, Tarapacá.

Trapezoidal tunic with curved lower border: (a) Yalquincha site (LMO1), Middle Loa (h. max. 180 mm) and (b) complex anthropomorphic from Jamajuga, Tarapacá.

referentes tejidos. La iconografía de los taparrabos y vestimentas rupestres y la existencia del grupo de túnicas en que se insertan las de Alto Ramírez tiene una distribución sorprendentemente amplia, vinculando al Loa con Tarapacá e, incluso, con el valle de Azapa (Agüero y Cases 2004; Horta 2004). De esto se deduce que durante el Formativo en el Norte Grande la información relativa a aspectos formales y tecnológicos de las túnicas y los tejidos en general circuló y se transfirió de manera más libre que en épocas posteriores, lo que repercutió en el registro rupestre.
Desde una mirada textil, nos parece importante destacar la temprana irrupción de una corporalidad vestida, culturalmente producida, donde los textiles empiezan a tener una creciente visibilidad. Este proceso debió encontrar sus orígenes en el Arcaico, potenciado por la domesticación y un creciente acceso a la fibra de camélidos. Es durante el Formativo Tardío (100-900 d.C.) que quedan en evidencia, en sitios fúnebres y rupestres, individuos con una corporalidad cubierta y, más aún, definida por el vestuario. En ambos contextos, las prendas textiles son paulatinamente incorporadas, hasta cobrar total 


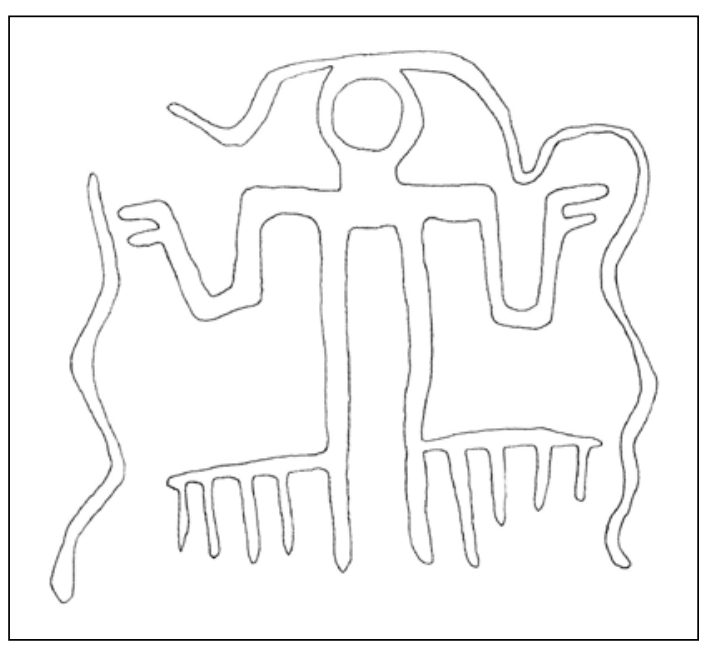

Figura 16. Dibujo de figura antropomorfa con faldellín de pabilos estructurados en axialidad, LS061, alto Loa (h. máx $840 \mathrm{~mm}$ ). Drawing of anthropomorphic figures with axial fringed pubic coverings, LS061, alto Loa (h. max. $840 \mathrm{~mm}$ ).

relevancia, llegando a hacerse más notorias que los rasgos anatómicos del mismo cuerpo (Montt 2005).

Posiblemente en el final del Formativo Tardío, en transición hacia el Período Intermedio Tardío, encontramos prendas rupestres de lados cóncavos y orilla curva, reminiscentes de la textilería tarapaqueña, vistiendo a un conjunto de antropomorfos enmarcados, interesantemente, entre las extremidades y vientre de un camélido de factura previa, estilo Taira, en el sitio homónimo. En el arte rupestre, a través de esta asociación verificamos conductas de reocupación, activación y mantención del espacio simbólico en este sitio. De ser correctas las apreciaciones cronológicas que sitúan estas formas entre el Formativo e Intermedio Tardío (ca. 750-950 d.C., Montt 2005:117), esta intervención reafirmaría el carácter abierto del sitio Taira hasta cerca del primer milenio de nuestra era y, en ese sentido, podría ser análogo a la cerámica ofrendada a los pies de estos paneles (Berenguer 1999, 2004a). Estos antecedentes permiten suponer que en algún nivel, el Alto Loa coparticipa de lo que hemos registrado en Quillagua durante el Formativo Tardío, es decir, una presencia material tarapaqueña que se hace más evidente hacia el final del período, que reutiliza y ritualiza espacios ocupados desde épocas más tempranas por gentes del Loa y, en ese sentido, atacameños (Agüero et al. 2006).

Ya desde el Formativo Temprano en los cementerios de la región se registra la presencia de túnicas, aunque escasas. Es sólo a partir del período Intermedio Tardío que ellas asumen preeminencia en el universo textil, adoptando una variabilidad morfológica, técnica y decorativa que es pesquisable en términos de su origen cultural. Su representación en el arte rupestre quizás se remonta a tiempos formativos, pero con toda seguridad sucede desde el Período Intermedio Tardío en adelante.

En el caso de las túnicas representadas en el arte rupestre del Loa Medio, nos parece relevante su combinación con lo que podría ser un taparrabo, una prenda textil propia del período Formativo Tardío. Destacamos esta combinación de prendas textiles en el arte parietal, porque parece coherente con un período Formativo, que en la cuenca del Loa se extiende hasta los inicios del período Intermedio Tardío. Por otra parte, nos parece relevante reconocer la posibilidad de una práctica de ataviarse con un carácter más local, que combina túnicas y taparrabos, que a su vez se diferencia del Alto Loa, donde sólo se registran túnicas en la expresión parietal. Adicionalmente, esto mostraría el tránsito experimentado en la representación de textiles en el arte rupestre, en el cual la atención se desplaza desde la parte inferior del cuerpo, cubierto en un principio por faldellines y taparrabos, al cuerpo superior vestido por túnicas. Entre éstas, son numéricamente más significativas aquellas rectangulares que, como hemos visto, se vincularían a Atacama, aunque por ahora no podamos asignarlas claramente al Formativo o al Intermedio Tardío.

A partir de este último período, la variedad formal en las túnicas parietales permite reconocer de manera más explícita los referentes textiles, siendo evidente una mayor diversidad formal en el Loa Medio que en la sección alta del mismo río. De tal modo, en el arte rupestre de ambos sectores encontramos representaciones bastante claras de tejidos de la región tarapaqueña y de la mixtura de elementos formales reconocida en el curso inferior en el dominio textil, que se inserta en un universo morfológico caracterizado por rasgos, que desde el textil, serían atacameños. Esta diversidad y combinatoria observada desde el registro textil en Quillagua encuentra un correlato en el arte rupestre y parece extenderse, entonces, al resto de la cuenca del Loa en un nivel que por ahora no estamos en condiciones de precisar. Esto ocurre en un momento -probablemente en el Intermedio Tardío- en que, a nivel interregional, se establecen nuevas opciones 
en las maneras de tejer que redundan en una configuración formal, por tanto visual, en el vestuario. Como ya señaláramos, en estos momentos es posible diferenciar las túnicas cuadradas a rectangulares como parte de la tradición textil de Atacama, de aquellas de Valles Occidentales, dentro de las que se inserta Tarapacá, con formas trapezoidales o semitrapezoidales, las cuales han sido caracterizadas principalmente a través del estudio de los textiles de Pica 8 (Agüero 2000 a y b, 2007). Aunque para el universo textil de Valles Occidentales sabemos que las túnicas rectangulares son las más recurrentes, los datos de Tarapacá entregados por Agüero (2007) señalan que las formas semitrapezoidales son características del Complejo Pica-Tarapacá, ya que las túnicas cuadradas y rectangulares que registra la autora se vinculan con tejidos atacameños, y en menor medida con Tiwanaku (Agüero 2007: 52-55). Estas diferencias morfológicas en las túnicas de ambas tradiciones textiles coexisten con aspectos tecnológicos. Nos referimos, en específico, al uso de una sola trama en los tejidos de Tarapacá y de tramas múltiples en los atacameños. Este atributo textil se dispone en los bordes laterales del tejido, cerrando y limitando el espacio textil; si bien en su contexto de producción la implementación de esta terminación debió ser significativa, en el contexto de uso del textil este atributo no es visible.

Lo que sucede en la constitución del textil, en el cual el espacio de forma atacameña es bordeado, finalizado, por medio de una solución técnica en la terminación de las orillas, realizada a la usanza de Tarapacá, o viceversa, resulta una situación interesante de indagar. Constituye un dispositivo que estructura el espacio textil de manera altamente evocativa respecto de la constitución del área ocupacional en Quillagua, donde se observa que un territorio con una materialidad atacameña -textil, cerámica y mortuoria- se encuentra circunscrito por una manifestación rupestre tarapaqueña de alta visibilidad como son los geoglifos (Núñez 1976; Montt 2005; Pimentel y Montt 2008). Parecen ser los bordes -del espacio tejido y ocupacional-el ámbito en que se integran las diferencias, en que ellas cobran significancia. Esta demarcación rupestre del espacio se estaría reproduciendo en los tramos más altos del Loa con otra técnica, escala, visibilidad e intensidad, diferencias que seguramente se vinculan también con que estos ámbitos y los sitios de arte rupestre aquí emplazados se relacionen con el tránsito y circulación y no a ocupaciones permanentes. De igual manera, esta mixtura entre espacios materialmente atacameños "delimitados" por expresiones rupestres tarapaqueñas nos resulta evocativa, además de los tejidos encontrados en el Loa Inferior, nuevamente en Quillagua, donde la mezcla se produce no sólo en lo formal (túnicas cuadradas con orilla curva), sino también entre este aspecto y lo tecnológico: formas tarapaqueñas tejidas a la usanza atacameña o viceversa (Agüero et al. 1999).

En la frontera Media y Alta del Loa, de este modo, podríamos interpretar que el vestuario rupestre, al igual que el textil, sirvió fundamentalmente en el Período Intermedio Tardío para mediatizar, negociar, compartir, contener y delimitar este espacio de tránsito, replicando lo que observábamos en Quillagua.

Por último, a través de este ensayo, hemos buscado subrayar la cualidad del río Loa como un área de frontera entre Tarapacá y Atacama no sólo en su tramo inferior, sino en toda su extensión, sumando los tejidos y su representación en el imaginario visual, al tradicional indicador cerámico. Con esto, consideramos que la mirada de este curso fluvial por parte de los investigadores debiera ampliar su Atacama-centrismo a otra más loína, que reconozca como característica local el contacto, convivencia y mixtura con Tarapacá donde la mezcla, en distintos grados, tiene cierta recurrencia tanto en el ámbito del vestuario textil como en el parietal, siendo esto último particularmente válido en el Intermedio Tardío. En tal sentido, suscribimos la idea de una unidad cultural y material atacameña, que presenta particularidades locales, siendo una de éstas la situación de la cuenca del Loa y su condición de frontera blanda, que se manifiesta en la transposición de vestimentas tarapaqueñas y atacameñas en el cuerpo de difuntos y figuras antropomorfas pintadas. Las manifestaciones rupestres de raigambre tarapaqueña que aquí se dan a conocer y discuten invitan a la misma reflexión que hemos desarrollado desde los textiles de Quillagua: que esta frontera -permeable- no existió sólo en el curso inferior del río Loa, sino en toda su cuenca, y en sus espacios productivos adyacentes. Por último, cabe agregar que la diversidad y mixtura formal y técnica en los textiles y, en este caso, en las túnicas representadas en el ámbito rupestre, posiblemente se vincula, tal como ya ha sido planteado desde datos coloniales, con unidades sociales segmentadas en el espacio e interdigitadas por medio del parentesco (Bittmann 1983; Martínez 1998; Odone 1994). 
Agradecimientos: A Francisco Gallardo responsable de los proyectos Fondecyt 1070083 y 1110702, en el primero de los cuales se enmarcó esta investigación y por facilitarnos la Figura 12 a como parte del registro de la investigación en curso; a Bernardita Brancoli por la elaboración de mapas y tablas; a Darel Gabriel Bridges por la elaboración de la Figura 1; a César Méndez por la elaboración de la Figura 2; a José Blanco por proporcionarnos las fotografías de la Figura 3; a
Flora Vilches y Gloria Cabello por facilitarnos la Figura 15 c; al apoyo recibido del proyecto Fondecyt 1111063 y al Convenio de Desempeño: Desarrollo Estratégico de las Humanidades, Ciencias Sociales y las Artes (CD HCSA), UTAMINEDUC. A los evaluadores anónimos cuyos comentarios y sugerencias han servido para enriquecer este escrito. Last, but not least, nuestra gratitud es con los antiguos artífices rupestres y textiles del Loa, Atacama y Tarapacá.

\section{Referencias Citadas}

Adán, L. 1996. Arqueología de lo Cotidiano. Sobre Diversidad Funcional y Uso del Espacio en el Pukara de Turi. Memoria para optar al Título de Arqueóloga. Universidad de Chile, Facultad de Ciencias Sociales, Santiago.

Adán, L. y M. Uribe 1995. Cambios en el uso del espacio en los períodos agroalfareros: un ejemplo de ecozona de quebradas altas, la localidad de Caspana (Provincia El Loa, II Región). Actas del II Congreso de Antropología Chilena, pp. 541-555. Valdivia.

- - - 1999. Aquellos antiguos edificios. Un acercamiento arqueológico a la arquitectura prehispánica tardía de Caspana. Estudios Atacameños 18:13-34.

Agüero, C. 1998. Estilos textiles de Atacama y Tarapacá y su presencia en Quillagua durante el Período Intermedio Tardío. Boletín del Comité Nacional de Conservación Textil 3:103-128.

- - - 2000a. Las tradiciones de Tierras Altas y de Valles Occidentales en la textilería arqueológica del valle de Azapa. Chungara Revista de Antropología Chilena 32:217-226.

- - - 2000b. Fragmentos para armar un territorio. La textilería en Atacama durante los períodos Intermedio Tardío y Tardío. Estudios Atacameños 20:7-28.

- - - 2007. El Vestuario en la Conformación y Consolidación de la Identidad Cultural de las Poblaciones de Tarapacá durante el Período Intermedio Tardío. Tesis para optar al Grado de Magíster en Antropología, Universidad Católica del NorteUniversidad de Tarapacá.

Agüero C. y B. Cases 2000. Los textiles formativos del norte de Chile. Informe de Avance, Proyecto Fondecyt 1990168. Manuscrito en posesión de las autoras.

- - - 2004. Quillagua y los textiles formativos del Norte Grande de Chile. Chungara Revista de Antropología Chilena Vol. Especial, Tomo II:599-617.

Agüero C., M. Uribe, P. Ayala y B. Cases 1999. Una aproximación arqueológica a la etnicidad y el rol de los textiles en la construcción de la identidad cultural en los cementerios de Quillagua (Norte de Chile). Gaceta Arqueológica Andina 25:167-197.

Agüero C., M. Uribe, P. Ayala, C. Carrasco y B. Cases 2006. El Período Formativo desde Quillagua (norte de Chile). En Esferas de Interacción Prehistóricas y Fronteras Nacionales Modernas: los Andes Sur Centrales, editado por H. Lechtman, pp.73-120. Instituto de Estudios Peruanos, Institute of Andean Research, Lima.

Aldunate, C. y V. Castro 1981. Las Chullpas de Toconce y su Relación con el Poblamiento Altiplánico en el Loa Superior Período Tardío. Ediciones Kultrun, Santiago.

Ambrosetti, J. 1895. Las grutas pintadas y los petroglifos de la Provincia de Salta. Boletín del Instituto Geográfico Argentino 16:311-342.

Arnold, D. 2000. “Convertirse en persona” el tejido: la terminología aymara de un cuerpo textil. Actas de la I Jornada Internacional sobre Textiles Precolombinos, pp. 9-28. Editado por V. Solanilla, Barcelona.

Arnold, D. y E. Espejo 2005. Las cabezas de la periferia, del centro y del mundo interior: una comparación de la iconografía bélica en los textiles arqueológicos de Paracas Topará y del Ayllu de Qaqachaka (Bolivia) contemporánea. En Tejiendo Sueños en el Cono Sur. Textiles Andinos: Pasado, Presente y Futuro, editado por V. Solanilla, pp. 348-364. Grup d’Estudis Precolombins, Universitat Autónoma de Barcelona, Barcelona.

Aschero, C. 2000. Figuras humanas, camélidos y espacios en la interacción circumpuneña. En Arte en las Rocas. Arte Rupestre, Menhires y Piedras de Colores en Argentina, editado por M.M. Podestá y M. de Hoyos, pp. 15-44. Sociedad Argentina de Antropología y Asociación de Amigos del Instituto Nacional de Antropología y Pensamiento Latinoamericano, Buenos Aires.

Ayala, P. 2000. Reevaluación de las Tradiciones Culturales del Período Intermedio Tardío en el Loa Superior: Caspana. Memoria para optar al Título Profesional de Arqueóloga, Universidad de Chile, Facultad de Ciencias Sociales, Santiago.

Ayala, P., O. Reyes y M. Uribe 1999. El cementerio de los Abuelos de Caspana: El espacio mortuorio local durante el dominio del Tawantinsuyu. Estudios Atacameños 18:35-54.

Berenguer, J. 1999. El evanescente lenguaje del Arte Rupestre en los Andes Atacameños. En Arte Rupestre en los Andes de Capricornio, editado por J. Berenguer y F. Gallardo, pp. 9-56. Museo Chileno de Arte Precolombino, Santiago.

- - - 2004a. Tráfico de Caravanas, Interacción Interregional y Cambio Cultural en la Prehistoria Tardía del Desierto de Atacama. Ediciones Sirawi, Santiago. 
- - - 2004b. Cinco milenios de arte rupestre en los Andes atacameños: Imágenes para lo humano, imágenes para lo divino. Boletín del Museo Chileno de Arte Precolombino 9:75-108.

Berenguer, J., V. Castro, C. Aldunate, C. Sinclaire y L. Cornejo 1985. Secuencia del arte rupestre en el Alto Loa: una hipótesis de trabajo. En Estudios en Arte Rupestre, editado por C. Aldunate, J. Berenguer y V. Castro, pp. 87-108. Museo Chileno de Arte Precolombino, Santiago.

Boman, E. 1992 [1908]. Antigüedades de la Región Andina de la República Argentina y del Desierto de Atacama. Universidad Nacional de Jujuy, S.S. de Jujuy, MCMXCII, Tomo II.

Briones, L. 2006. The Geoglyphs of the north Chilean desert: an archaeological an artistic perspective. Antiquity 80:9-24.

Cáceres, I. y J. Berenguer 1996. El caserío de Santa Bárbara 41, su relación con la Wak'a de Taira, Alto Loa. Chungara Revista de Antropología Chilena 28:381-393.

Cases, B. 2002. Sobre la relación de grupos textiles y cerámicas del Loa (Período Intermedio Temprano o Formativo). Informe final Proyecto Fondecyt 1990168. Manuscrito en posesión de la autora.

- - - 2007. Continuidad, Cambio y Variaciones en las Bolsas Domésticas de Quillagua durante el Período Intermedio Tardío. Tesis para optar al grado de Magíster en Antropología. Instituto de Investigaciones Arqueológicas y Museo R. P. Gustavo Le Paige de la Universidad Católica del Norte y Departamento de Arqueología y Museología de la Universidad de Tarapacá.

Cases, B. y C. Agüero 2004. Textiles teñidos por amarras en Chile prehispánico. Estudios Atacameños 27:117-138.

Castro, V., C. Aldunate, J. Berenguer, L. Cornejo, C. Sinclaire y V. Varela 1994. Relaciones entre el noroeste argentino y el norte de Chile: el sitio 02-TU-002, vegas de Turi. En Taller de Costa a Selva: Producción e Intercambio entre los Pueblos Agroalfareros de los Andes Centro Sur, editado por M. E. Albeck, pp. 215-239. Instituto Interdisciplinario de Tilcara, Jujuy, Argentina.

Cervellino M., y F. Téllez 1980. Emergencia y Desarrollo en una Aldea Prehispánica de Quillagua-Antofagasta. Contribución Arqueológica, $\mathrm{N}^{\circ} 1$ (Copayapu), DIBAM, Museo Regional de Atacama, Copiapó.

Chacama, J. y G. Espinoza 2005 [1999]. La ruta de Tarapacá: Análisis de un mito y una imagen en el norte de Chile. Rupestreweb. http://rupestreweb2.tripod.com/tarapaca.html, (20 marzo 2006).

Cobo, B. 1956 [1653]. Historia del Nuevo Mundo. Editorial Atlas, Madrid.

Gallardo F., L. Cornejo, R. Sánchez, B. Cases, A. Román y A. Deza 1993. Arqueología en el valle de Quillagua, río Loa, Norte de Chile. Gaceta Arqueológica Andina 23:125-138.

Horta, H. 2000. El arte rupestre de Taira. Definición estilística e iconográfica. Revista de Teoría del Arte 2:83-155.

- - - - 2004 Iconografía del Formativo tardío del norte de Chile. Propuesta de definición e interpretación basada en imágenes textiles y otros medios. Estudios Atacameños 27:45-76.

Horta, H. y J. Berenguer 1995. Un ícono formativo en el arte rupestre del Alto Loa. Boletín de la Sociedad Chilena de Arqueología 20:23.
Latcham, R. 1938. Arqueología de la Región Atacameña. Prensas de la Universidad de Chile, Santiago.

López, P. 1979. Emergencia y Desarrollo de una Aldea Prehispánica de Quillagua, Antofagasta. Memoria para optar al título de Arqueólogo. Universidad de Antofagasta.

Lumbreras, Luis G. 1981. Arqueología de la América Andina. Editorial Milla Batres, Lima.

Manríquez, V. 2002. De Atacamas y Atacameños. La construcción de identidades en Atacama Colonial (siglos XVI y XVII), Informe Proyecto Fondecyt 1000148. Manuscrito en posesión de la autora.

Martínez, J.L. 1998. Pueblos del Chañar y el Algarrobo. Los Atacamas en el siglo XVII. Ediciones de la Dirección de Bibliotecas, Archivos y Museos, Santiago.

Montell, G. 1926. An Archaeological Collection from the Río Loa Valley, Atacama. Etnografisk Museum Skrifter, Oslo.

Montt, I. 2002a. Instalaciones funerarias del Período Intermedio Temprano en el Norte Grande de Chile, Informe de avance Proyecto Fondecyt 19900168. Manuscrito en posesión de la autora.

- - - 2002b. Faldellines del Período Formativo en el Norte Grande: Un ensayo acerca de la historia de su construcción visual. Estudios Atacameños 23:7-22.

- - - 2004. Elementos de atuendo e imagen rupestre en la subregión de Río Salado, Norte Grande de Chile. Chungara Revista de Antropología Chilena Vol. Especial, Tomo II:651-661.

- - - 2005 Vestimenta en la Cultura Visual Tardía del Desierto de Atacama. Memoria para optar al Título de Arqueóloga. Universidad de Chile.

Montt, I. y G. Pimentel 2009. Grabados antropomorfos tardíos. El caso de las personificaciones de hachas en San Pedro de Atacama. En Crónicas sobre la Piedra. Arte Rupestre de las Américas, editado por M. Sepúlveda, L. Briones y J. Chacama, pp. 221-233. Ediciones Universidad de Tarapacá, Arica.

Núñez, L. 1969. El primer fechado radiocarbónico del Complejo Faldas del Morro en el sitio Tarapacá 40, y algunas discusiones básicas. Actas V Congreso Nacional de Arqueología Chilena, pp. 47-57. La Serena.

- - - 1976. Geoglifos y tráfico de caravanas en el desierto chileno. En Homenaje al Dr. R. P. Gustavo Le Paige, editado por H. Niemayer, pp. 147-201. Universidad del Norte, Antofagasta.

- - - 1984. Tráfico de Complementariedad de Recursos entre las Tierras Altas y el Pacífico en el Área Centro-Sur Andina. Tesis Doctoral. Universidad de Tokio, Departamento de Antropología Cultural.

Odone, C. 1994. La territorialidad indígena y española en Tarapacá colonial (siglos XVI-XVIII): una proposición. Tesis para optar al grado de Licenciada en Historia. Pontificia Universidad Católica de Chile. Santiago.

Oyarzún, A. 1981 [1931]. Tejidos de Calama. Estudios Antropológicos y Arqueológicos, Editorial Universitaria, Santiago de Chile.

Pimentel, G. e I. Montt 2008. Tarapacá en Atacama. Arte rupestre y relaciones intersocietales entre el 900 y 1450 DC. Boletín del Museo Chileno de Arte Precolombino 13:35-50. 
Posnasky, A. 1937. Antropología y Sociología de las Razas Interandinas y de las Regiones Adyacentes. Instituto Tihuanacu de Antropología, Etnografía y Prehistoria, Editorial Renacimiento, La Paz.

Ryden, S. 1944. Contribution to the archaeology of the Rio Loa Region. Elanders Boktryckery Aktiebolag. Gotemburgo.

Sanhueza, C. 1992. Tráfico caravanero y arriería colonial en el siglo XVI. Estudios Atacameños 10: 169-182.

Sinclaire, C. 1997. Pinturas Rupestres y textiles formativos en la región atacameña. Estudios Atacameños 14:327-338.

- - - 2004 Prehistoria del Período Formativo en la cuenca alta del río Salado (Región del Loa Superior): un estado de la cuestión. Chungara Revista de Antropología Chilena Vol. Especial, Tomo II:619-639.

Vilches, F. y Cabello, G. 2010. Arte rupestre y asentamiento en el Complejo Pica-Tarapacá: las imágenes como indicadores de identidad y complejidad social. Actas XVII Congreso Nacional de Arqueología Chilena, Vol. 2, pp. 671-680. Valdivia.

- - - 2011. Variaciones sobre un mismo tema: el arte rupestre asociado al Complejo Pica-Tarapacá, norte de Chile. Chungara Revista de Antropología Chilena 43:37-52.

Uhle, M. 1913. Los indios atacameños. Revista Chilena de Historia y Geografía 9:105-111.

Uribe, M. 1996. Religión y Poder en los Andes del Loa: una Reflexión desde la Alfarería (Período Intermedio Tardío). Memoria para optar al título de arqueólogo, Dpto. de Antropología, Universidad de Chile, Santiago.
- - - 2002 Sobre Alfarería, cementerios, fases, procesos y la construcción de Atacama en la prehistoria Tardía (800-1600 DC). Estudios Atacameños 22:7-31.

- - - 2006. Acerca de la complejidad, desigualdad social y el complejo cultural Pica-Tarapacá en los Andes Centro- Sur (1000-1450 DC). Estudios Atacameños 31:91-114.

- - - 2009. El período Formativo de Tarapacá y su cerámica: Avances sobre complejidad social en la costa del norte grande de Chile (900 AC-800 DC). Estudios Atacameños 37:5-27.

Uribe, M., L. Adán y C. Agüero 2002. El domino del Inka, identidad local y complejidad social en las Tierras Altas del Desierto de Atacama, Norte Grande de Chile (1450-1541 DC). Boletín de Arqueología PUPC 6:301-336.

Uribe, M., L. Sanhueza y F. Bahamondes 2007. La cerámica prehispánica tardía de Tarapacá, sus valles interiores y costa desértica, Norte de Chile (ca. 900-1450 DC): Una propuesta tipológica y cronológica. Chungara Revista de Antropología Chilena 39:143-170.

Varela, V., Uribe, M. y L. Adán 1993. La cerámica Arqueológica del sitio "Pukara" de Turi: 02-TU-001. Actas del XII Congreso Nacional de Arqueología Chilena Boletín Museo Regional de la Araucanía Tomo II, No 4:107-122.

Williams, V. I., C. Santoro, A. Romero, J. Gordillo, D. Valenzuela y V. Standen 2009. Dominación Inca en los Valles Occidentales (Sur del Perú y Norte de Chile) y el Noroeste Argentino. Andes 7:615-654.
1 Ésta se extiende desde el sur del Salar de Uyuni, en Bolivia, abarcando el altiplano Lípez, la puna de Atacama en Chile y la de Jujuy en Argentina, hasta el paso San Francisco por el Sur. Abarca, por lo tanto, las vertientes occidental y oriental de los Andes. La vertiente occidental limita con el Pacífico, desde el norte del río Loa hasta Chañaral por el sur, mientras que la vertiente oriental lo hace entre las cabeceras y valles de la región de Humahuaca hasta el borde del Chaco, siguiendo hacia el sur, cerca de los valles de Salta y Jujuy (Aldunate y Castro 1981; Sanhueza 1992).

2 La subárea de Valles Occidentales del área Centro Sur Andina, es referida por Lumbreras (1981), Aldunate y Castro (1981), Núñez (1984), Agüero (2007) y Williams et al. (2009) como los valles comprendidos entre Majes (Perú) por el Norte y el río Loa por el sur.

3 En un principio, Montt (2005) propone que las vestimentas de lado cóncavo podrían corresponder a túnicas ceñidas por una faja, la que no es representada. Asimismo, otra propuesta es que se trate de petos de cuero, escasos en los contextos del Loa Medio (Latcham 1938; Montell 1926; Posnasky 1937; Ryden 1944), y no siempre de forma cóncava en sus lados (ver Montt 2005, Figura 10.1).

4 Este término, acuñado por colegas argentinos y nacionales desde Ambrosetti (1895) en adelante, se ha utilizado equivocadamente para nombrar representaciones de personajes con "vestimentas" con apéndices aguzados en su parte superior y concavidades en su parte medial, que en nada se asemejan a la morfología de los escudos. Por el contrario, estos elementos se asemejan en su morfología a las hachas de metal o piedra (Aschero 2000), por lo que se utiliza para las figuras que los portan el nombre de hombres hacha o personificaciones de hachas (Montt y Pimentel 2009).

5 Las vestimentas de estas figuras antropomorfas, en particular la concavidad de sus costados y el largo respecto del tronco y las extremidades de la figura antropomorfa, recuerdan a algunas pendas grabadas adscritas al estilo La Isla (Berenguer 1999: 30, figura inferior derecha). Dichas prendas han sido denominadas por Horta (2000) como túnicas largas.

6 En el sitio Tarapacá 40 A estos faldellines son reportados por Núñez (1969) como populares. Sin embargo, los trabajos de registro de la colección textil del sitio homónimo efectuados por Agüero y Cases (2000) no encuentran estas prendas en las colecciones que revisan. Para mayores antecedentes véase Montt (2004).

7 Llamados en trabajos anteriores como vestimenta de lado cóncavo y falda continua, respectivamente (Montt 2002, 2004, 2005). 
